May 2002 • NREL/TP-620-32155

\title{
Green Power Marketing Abroad: Recent Experience and Trends
}

\author{
Lori Bird
}

National Renewable Energy Laboratory

Rolf Wüstenhagen

University of St. Gallen (Switzerland)

Jørn Aabakken

National Renewable Energy Laboratory

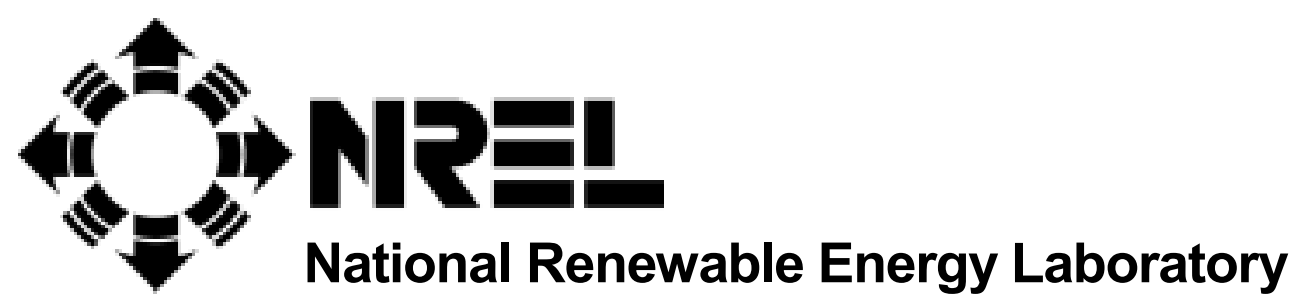

1617 Cole Boulevard

Golden, Colorado 80401-3393

NREL is a U.S. Department of Energy Laboratory

Operated by Midwest Research Institute $\bullet$ Battelle $\bullet$ Bechtel

Contract No. DE-AC36-99-G010337 


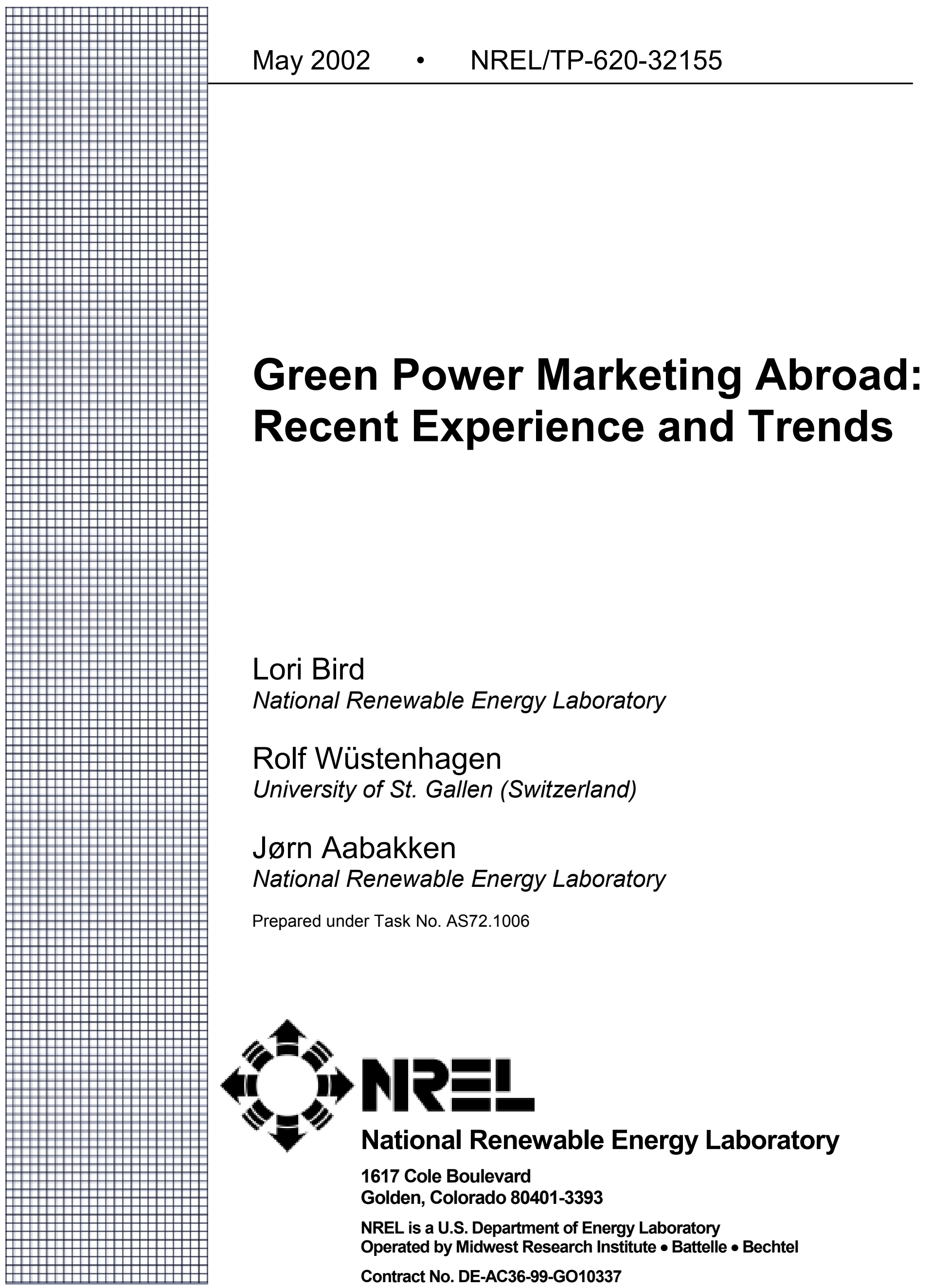




\section{NOTICE}

This report was prepared as an account of work sponsored by an agency of the United States government. Neither the United States government nor any agency thereof, nor any of their employees, makes any warranty, express or implied, or assumes any legal liability or responsibility for the accuracy, completeness, or usefulness of any information, apparatus, product, or process disclosed, or represents that its use would not infringe privately owned rights. Reference herein to any specific commercial product, process, or service by trade name, trademark, manufacturer, or otherwise does not necessarily constitute or imply its endorsement, recommendation, or favoring by the United States government or any agency thereof. The views and opinions of authors expressed herein do not necessarily state or reflect those of the United States government or any agency thereof.

Available electronically at http://www.osti.gov/bridge

Available for a processing fee to U.S. Department of Energy

and its contractors, in paper, from:

U.S. Department of Energy

Office of Scientific and Technical Information

P.O. Box 62

Oak Ridge, TN 37831-0062

phone: 865.576.8401

fax: 865.576 .5728

email: reports@adonis.osti.gov

Available for sale to the public, in paper, from:

U.S. Department of Commerce

National Technical Information Service

5285 Port Royal Road

Springfield, VA 22161

phone: 800.553 .6847

fax: 703.605.6900

email: orders@ntis.fedworld.gov

online ordering: http://www.ntis.gov/ordering.htm 


\section{Acknowledgments}

This work was funded by the U.S. Department of Energy's (DOE) Office of Energy Efficiency and Renewable Energy.

The authors also wish to thank the following reviewers for their thoughtful comments and suggestions: Allan Andersen of the Danish Society for the Conservation of Nature, Tore Brænd of the Norwegian Society for the Preservation of Nature, Paula Cribb of the Sustainable Energy Development Authority (Australia), Jon Dogterom of the Pembina Institute (Canada), Heddeke Heijnes of Greenprices (The Netherlands), Anne Louise Koefoed of the Norwegian School of Management, Sven Frauenfelder of Linder Kommunikation (Switzerland), Theresa Howland of Enmax (Canada), Tomas Kaberger of Ecotraffic (Sweden), Gero Lücking of Lichtblick (Germany), Maja Marlier of the ICHEC Business School (Belgium), Mika Ohbayashi of the Institute for Sustainable Energy Policies (Japan), Eveline Steinberger of Verbund (Austria), Ursula Stocker and Cornelia Brandes of Naturemade (Switzerland), Sven Teske of Greenpeace Energy (Germany), Sirkka Tepponen of the Finnish Association for Nature Conservation, Elaine Waterson of the Energy Saving Trust (United Kingdom), and Blair Swezey and Larry Goldstein of the National Renewable Energy Laboratory (NREL). The authors would also like to thank Caroline Hopkins of the Swedish Society for Nature Conservation, Philip Lewis of the University of Vaasa (Finland), and Andrew Pape-Salmon of the Pembina Institute (Canada) for information they provided for early drafts. Lastly, the authors wish to thank Barbara Kündig for research support and Michelle Kubik of NREL for her editorial review. 


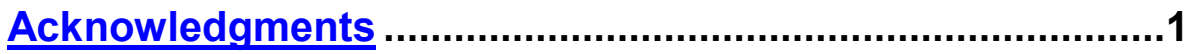

Executive Summary..............................................................

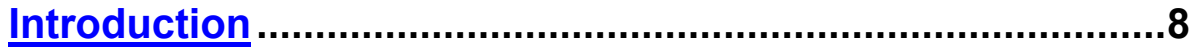

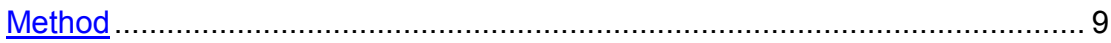

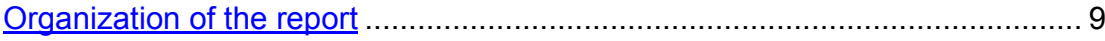

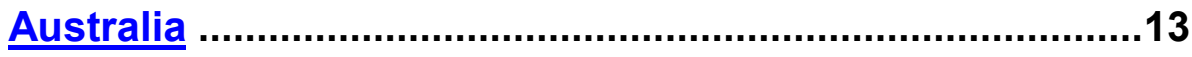

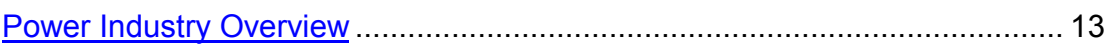

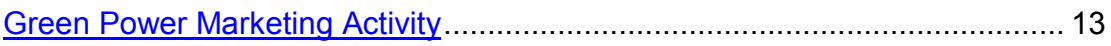

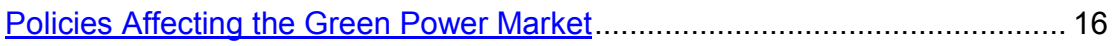

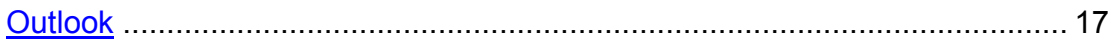

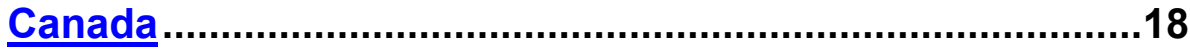

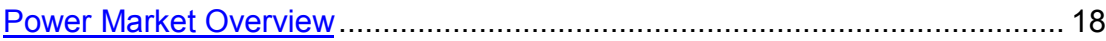

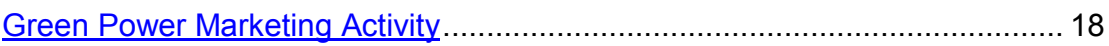

Policies Affecting the Green Power Market................................................... 21

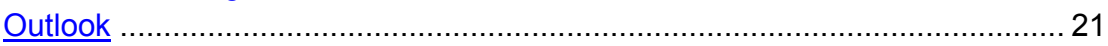

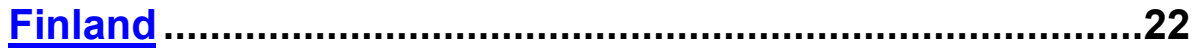

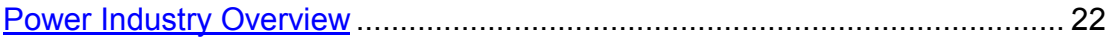

Green Power Marketing Activity .............................................................. 22

Policies Affecting the Green Power Market.................................................. 23

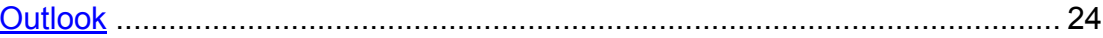

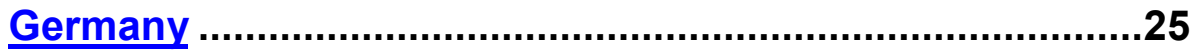

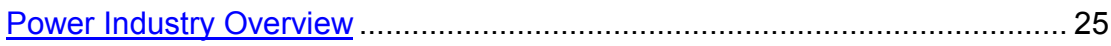

Green Power Marketing Activity........................................................... 25

Policies Affecting the Green Power Market..................................................... 29

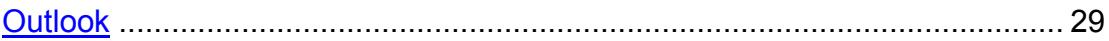

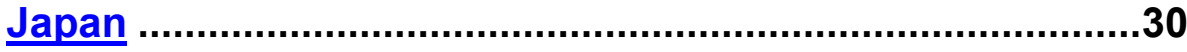

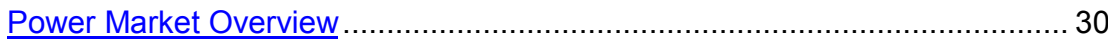

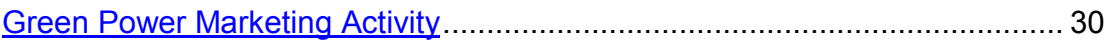

Policies Affecting the Green Power Market...................................................... 31

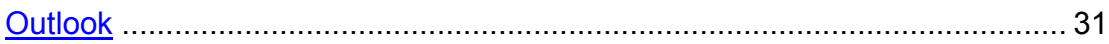

The Netherlands..................................................................32

Power Market Overview........................................................................... 32

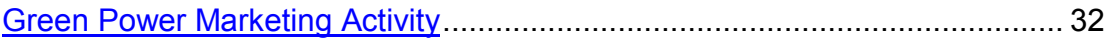

Public Policy Support for the Green Power Market .......................................... 35

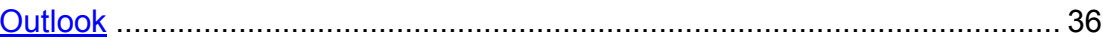

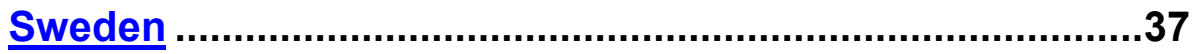

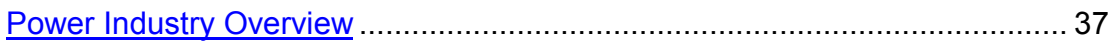

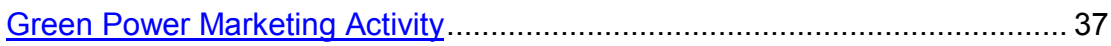




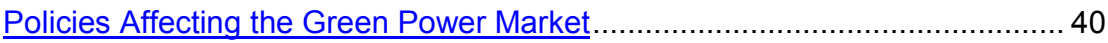

Outlook ...................................................................................... 40

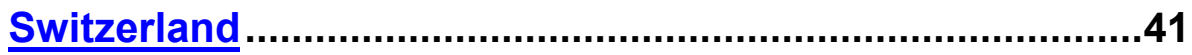

Power Market Overview...................................................................... 41

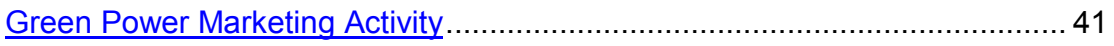

Policies Affecting the Green Power Market.............................................. 44

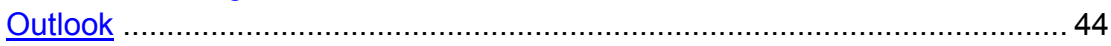

United Kingdom .................................................................45

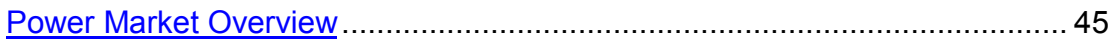

Green Power Marketing Activity ............................................................. 45

Policies Affecting the Green Power Market.................................................. 48

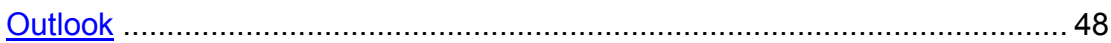

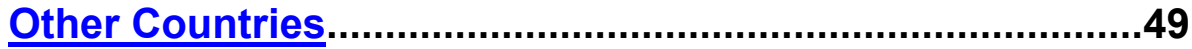

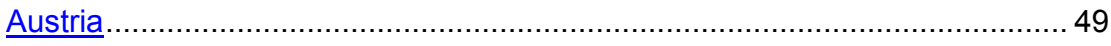

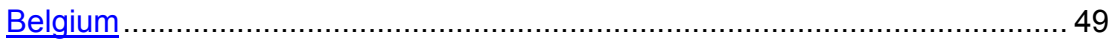

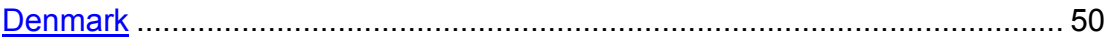

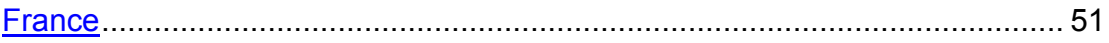

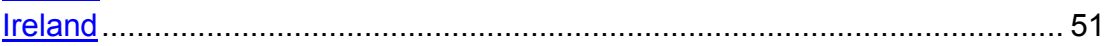

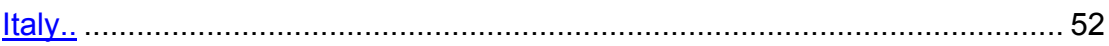

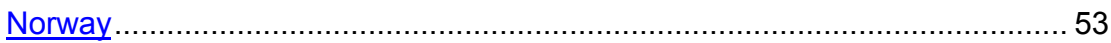

Comparison of Markets: Consumer Response and Issues Affecting Green

Power Market Development.........................................55

Consumer Response ............................................................................. 55

Product Design and Renewable Content ............................................. 55

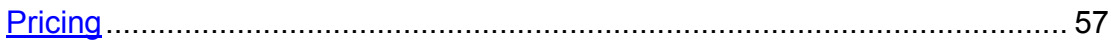

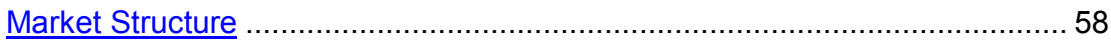

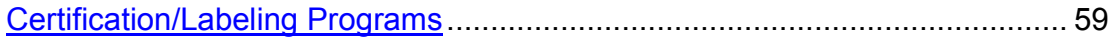

Impact of Renewable Energy Policies on the Green Power Market.................. 59

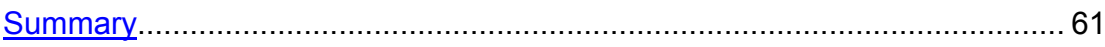

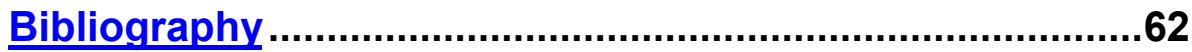




\section{Executive Summary}

Green power marketing - the act of differentially selling electricity generated wholly or in part from renewable sources - has emerged in more than a dozen countries around the world. In the United States, green power marketers have been active for several years but the market is young and experience is still rather limited. We have undertaken a review of green power marketing activity in other countries to gain additional perspective on consumer demand and to discern key factors or policies that affect the development of green power markets. Specifically, we explore which particular product designs, market structures, incentive programs, marketing strategies, or other factors lead to more robust green power markets. The objective is to determine what lessons can be gleaned from other markets and applied to green power markets in the United States.

Key findings include:

- While market penetration rates for green power have typically been about $1 \%$, the most successful markets have achieved penetration rates of between $5 \%$ and $15 \%$. Consumer demand for green power has been highest in the Netherlands, where about $13 \%$ of residential customers have chosen green power, and Sweden, where green power represents about $6 \%$ of all electricity sales. The relative success of the Dutch market can be explained, in part, by aggressive marketing campaigns by utilities and marketers, a restructuring policy that has allowed early access to retail green power suppliers, and tax exemptions for green power purchases. In Sweden, the market has been driven by the availability of large quantities of existing hydropower that can be sold at relatively low prices.

- Customer education and aggressive marketing is necessary. In general, we found that a lack of aggressive and targeted marketing on the part of green power suppliers is one of the most important factors limiting consumer response to these products. Lack of knowledge of green power products is widespread and can best be overcome by combined efforts of existing utilities, new market entrants, labeling organizations, nongovernmental organizations, and perhaps government agencies. Multiple marketing efforts or combined efforts (i.e., environmental organizations teaming with marketers) can raise awareness in the overall market. Equally important is carefully targeting the most promising customer segments using a variety of communication channels that enable customers to understand the new product. Retaining customers by providing them with information on the status of the program and recognizing their participation is also important.

- Green power marketers have offered a range of products to appeal to customers with varying price sensitivities and resource preferences. The majority of products consist of blends of renewable resources, such as biomass, hydro, wind, and solar, offered at moderate to low price premiums. In some European countries, the inclusion of large hydro has been common, whereas its use has been limited to small or low-impact projects in other areas. Generally, products heavily dependent on existing, large hydro resources have been sold at the same price as system power or at very modest 
premiums, which are then typically used to fund mitigation efforts and environmental improvements at affected waterways. For customers interested in purchasing products that will result in more significant environmental improvements, utilities and marketers have offered products featuring, most commonly, new wind or sometimes solar, with these typically carrying the highest price premiums. In Germany, in particular, cogeneration with natural gas has also been included in green power products, based on its environmental benefits relative to the overall system mix. This demonstrates that there is a certain correspondence between a country's existing power generation structure and the type of green power products that emerge.

- The impact of green power marketing on new renewables development has been limited so far. Much of the green power sold in competitive electricity markets today has been supplied from existing renewable resources. In Europe, large hydropower projects have supplied the bulk of the electricity. A number of programs have led to the installation of new rooftop PV systems; however, these projects are small in terms of overall capacity. In general, the amount of new renewable capacity added to serve green power customers has been limited; although, in many areas, it is expected that additional capacity will be constructed to meet demand as a result of supply deficiencies and requirements for new generation instituted by certification organizations. Already, significant capacity additions are underway in Australia, where certified suppliers are now required to source $80 \%$ of their green electricity sales from new facilities. Overall, there is generally some delay between the launch of programs and the installation of new projects to serve customers. Thus, to some extent, the lack of substantial new capacity reflects the early stage of market development.

- While price is not the only important driver of demand, companies offering lowerpriced products have generally obtained more customers. Most green power products have been offered at modest price premiums on the order of U.S. $0.5 \mathrm{~d} / \mathrm{kWh}$ to $1.5 \phi / \mathrm{kWh}$. In some cases, green power has been offered at prices below standard electricity service, such as in Germany, Finland, and the Netherlands. On the other hand, a number of products, typically those that have featured new wind or solar resources, have been offered at relatively high price premiums in the range of U.S. $2 \phi / \mathrm{kWh}$ to $6 \phi / \mathrm{kWh}$ or more. These higher-priced products have been targeted at the most environmentally concerned consumers interested in purchasing high-quality products that yield the greatest environmental benefits. Overall, price appears to significantly influence demand as is evidenced by experience in The Netherlands, Germany, and Sweden; but it is clearly not the only factor. In Finland, for example, green power has been offered at a discount to conventional power, yet consumer response has been fairly modest.

- Retail competition can stimulate green power marketing activity. A number of markets experienced a flurry of activity when residential customers first gained access to competitive suppliers. The threat of competition has also spurred incumbent suppliers to offer green energy choices. Prior to the onset of retail competition, utilities have, in many cases, offered green power to their captive customers to 
encourage customer loyalty when competition ensues and to gain experience marketing differentiated products.

- Many customers have purchased green power without switching suppliers. In countries reviewed in this report, typically less than a third of customers purchasing green power do so through an alternative supplier. This reflects the fact that, in general, switching activity in retail electricity markets has remained low in many countries. Experience from other newly competitive markets, such as telecommunications, suggests that switching is likely to increase over time as markets mature. Thus, one possible explanation for the lack of switching could be the immature nature of the competitive electricity markets considered here. However, because the movement toward competitive electricity markets has slowed in some markets and barriers to switching remain high for residential customers, we may continue to see a majority of customers buy green power from incumbent suppliers.

- Certification and labeling programs can play an important role in shaping products. Certification programs have emerged as important vehicles for verifying renewable energy supplies and ensuring that products have true environmental benefits. Most certification programs have influenced the types of renewables offered and generally led to higher-quality products. A few European certification programs have tried to ensure that some environmental benefit is derived from existing, large hydro projects by requiring suppliers to undertake mitigation activities at affected waterways. Certification organizations have also served as primary drivers for the inclusion of power from new renewable energy sources. Government-sponsored labels have been very successful in both Canada and Australia, while a majority of the labels elsewhere have been created by non-governmental organizations. Coordination of national labeling approaches and determining how green energy labels and tradable green certificates will interact are emerging issues.

- Government support can be an important facilitator of green power market development. Tax exemptions or credits for green power purchases are one of the most direct forms of government assistance for the green power market. These have been successful in stimulating supply and demand for green power, most notably in the Netherlands. Tax incentives can directly lower the costs of green power and can improve profit margins for marketers, enabling them to more easily compete in the market and undertake more aggressive marketing campaigns. In addition, government commitments to purchase green power have been successful in stimulating markets in some regions.

- The impact of purchase obligations and similar policies designed to support renewables is still unclear, but uncertainty in policy development can stifle markets. Countries such as Australia, Belgium, Denmark, Sweden, and the United Kingdom have adopted or plan to implement purchase obligations (or renewable portfolio standards, as they are known in the United States), requiring retail suppliers to obtain some portion of the generation in their resource portfolio from renewables. These policies have the potential to impact consumer demand for green power in that 
customers might not be willing to pay a premium for green power if a portion of their power is already supplied from renewables. Australia's purchase obligation took effect in 2001 and the impact appears to be negligible so far. Overall, most policies have only recently been adopted and, thus, it is too early to determine their impacts. However, uncertainty surrounding the purchase obligation in Denmark appears to have largely stifled the development of the green power market.

In summary, we find that market penetration rates beyond $10 \%$ are achievable if market conditions are favorable to green power. Most markets, however, have experienced penetration rates of about $1 \%$ or less, similar to the United States. In general, green power markets are young and, as is the case with most new markets, require time to develop. Based on our review, the following factors can aid in fostering the development of green power markets: aggressive and cooperative marketing efforts by utilities and competitive providers, incentives and other policies that reduce the cost of renewable energy, restructuring rules that give priority to green power customers, market rules that enable competition to ensue, certification standards that encourage new renewables development, government purchases that stimulate demand, and consumer education that addresses the availability and benefits of green power options. 


\section{Introduction}

Throughout the world, many electricity customers are gaining the power to choose their electricity providers. Green power marketing - the act of differentially selling electricity generated wholly or in part from renewable sources - has emerged in more than a dozen countries across the globe. In this report, we examine green power marketing experience outside of the U.S. to determine if there are lessons that can be applied to domestic green power markets. Experience from other countries may provide additional insight into consumer demand for green power, successful marketing strategies, and the interplay between green markets and renewable energy policies.

In the United States, the first green power offerings appeared in the early 1990s. These programs, offered by utilities in regulated markets where customers are not given the choice of suppliers, are referred to as green pricing programs. Today, more than 90 utilities in 31 states offer optional green pricing programs. The number of programs has grown steadily during the past few years, with between 15 and 25 new programs appearing annually. On average, about $1 \%$ of utility customers participate in green pricing programs, with the most successful programs achieving participation rates in the range of $4 \%$ to $7 \%$.

In addition to utility programs, power marketers also offer green power options to retail customers in states that have opened their power markets to competition-we refer to these offerings as green power marketing programs. The first competitively marketed products appeared in the late 1990s when states such as California and Pennsylvania opened their markets to competition. Today marketers also offer retail green power products in Maryland, New Jersey, New England, Texas, and Virginia.

Collectively, about one-third of U.S. electricity customers have the option to purchase green power directly from a marketer or their utility. More than 375,000 customers, or about $1 \%$, have done so. ${ }^{1}$ Green power sales have resulted in the development of about $650 \mathrm{MW}$ of new renewables capacity, while another $440 \mathrm{MW}$ are either already under construction or formally announced. Experience with U.S. green power marketing has been documented by Swezey and Bird (2000; 2001) and Wiser et al (2001) and will not be discussed in detail in this report. Rather the focus here is on international experience with green power marketing and the lessons that can be learned from these markets.

Outside of the U.S., green power is offered in Canada, Japan, Australia, and about a dozen European countries. The purpose of this report is to 1) survey international green power marketing activity, 2) determine whether there are particular market structures, marketing strategies, policies, or other factors that lead to more robust green power markets, and 3) determine if there are lessons and concepts that can be applied to the U.S. market. Specifically, we examined the following questions. Have some countries achieved higher rates of market penetration than the United States? Is customer response affected by the price of green power products? Does it matter whether the market is open

\footnotetext{
${ }^{1}$ In addition, marketers supply an estimated 450,000 customers with "clean" electricity products in which a small portion of the electricity is generated from renewables (e.g., 1-2\%).
} 
to competition or whether customers must switch suppliers to purchase a green product? Do certain market rules encourage or inhibit growth of the green power market? Are there mechanisms or institutions that have been particularly successful in facilitating the sale of green power, such as product certification programs or renewable energy certificate trading programs? And finally, are there particular renewable energy policies that have stimulated a greater level of green power marketing activity? In this report, we attempt to answer some of these questions and draw lessons from experience in other countries that could be applicable to the U.S. market.

\section{Method}

In the preparation of this report, we identified countries in which green power marketing has been underway for several years and those in which the market is just emerging. We obtained information on market activity through literature reviews, news reports, and discussions with marketers, environmental stakeholders, market analysts, as well as representatives of product certification programs, utilities, and government agencies. We also conducted Internet searches to obtain information on the leading green power marketers. Whenever possible, we collected information on the number of marketers, the types of products offered, product content and pricing, consumer response ${ }^{2}$, and new renewable resource development stimulated by green power purchases. In many cases, certification programs provided much of the data on product offerings and response rates. We also relied on reviews by regional green power marketing experts to ensure the accuracy of our data and analyses.

\section{Organization of the Report}

The following sections summarize green power marketing activity in Australia, Canada, Japan, and roughly a dozen European countries (see Figure 1). In each section, we discuss the market structure, the level of green power marketing activity, green power products and pricing, certification programs, and policies that affect the market for green power. We also assess the potential of the green power market to grow in the short term based on recent activity and market conditions. Table 1 provides a summary of the countries included in this study and includes our assessment of the level of green power marketing activity currently underway. Detailed discussions have been prepared for those countries that have achieved a notable level of green power marketing activity, while shorter discussions are provided for countries with emerging markets. Table 2 shows the relative size of the various power markets, including estimates of the number of electricity customers, total electricity demand, the price of electricity, and total generating capacity. The report concludes with a comparison of the green power marketing experience in the countries reviewed here.

\footnotetext{
${ }^{2}$ Estimates of green power customers are often based on marketer claims and, thus, have some degree of uncertainty. Whenever possible, we sought independent verification, but all remaining inaccuracies are solely in the authors' responsibility.
} 


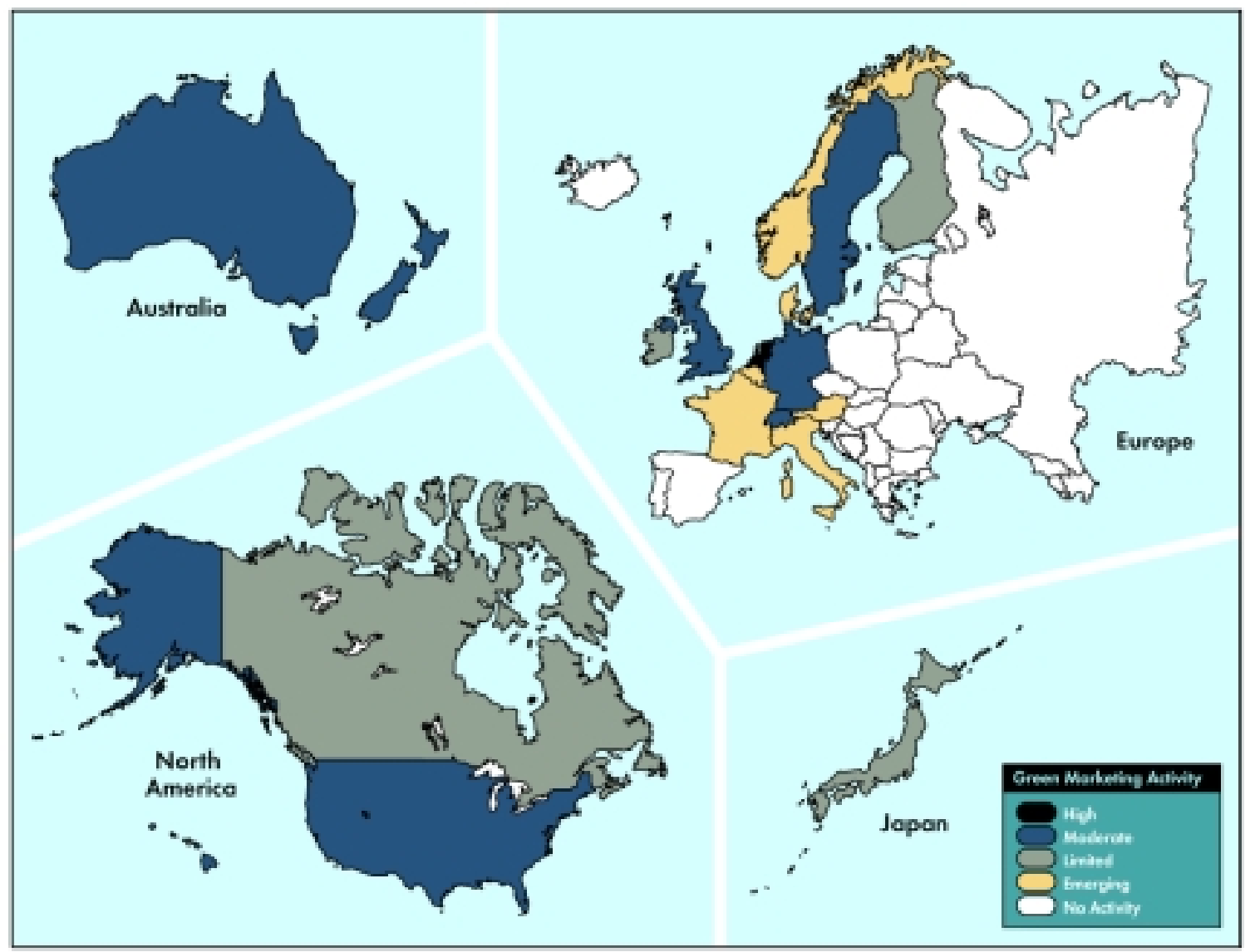

Figure 1: Countries with Current or Emerging Green Power Markets 
Table 1: Market Status and Green Power Marketing Activity

\begin{tabular}{|c|c|c|c|}
\hline & Market Status & $\begin{array}{l}\text { Green Marketing } \\
\text { Activity }\end{array}$ & $\begin{array}{l}\text { Start of Green Power Market } \\
\text { Activity }\end{array}$ \\
\hline Australia & $\begin{array}{l}\text { Most customers have retail choice; some } \\
\text { states have delayed restructuring }\end{array}$ & Moderate & $\begin{array}{l}\text { First utility programs launched } \\
\text { in mid-1990s }\end{array}$ \\
\hline Austria & $\begin{array}{l}\text { Market fully open to competition since } \\
\text { October } 2001\end{array}$ & Emerging & $\begin{array}{l}\text { First green power offerings } \\
\text { launched in } 2001\end{array}$ \\
\hline Belgium & $\begin{array}{l}\text { Undergoing restructuring, large and mid-sized } \\
\text { businesses have retail access; green electricity } \\
\text { customers have choice in Flemish region }\end{array}$ & Emerging & To be determined \\
\hline Canada & $\begin{array}{l}\text { Partially open to competition; Alberta has } \\
\text { retail competition, Ontario to open mid-2002 }\end{array}$ & Limited & $\begin{array}{l}\text { First utility programs launched } \\
\text { in late 1990s. }\end{array}$ \\
\hline Denmark & $\begin{array}{l}\text { Large customers gained direct access in } 1999 \text {, } \\
\text { all customers will have retail choice starting in } \\
2003\end{array}$ & Emerging & $\begin{array}{l}\text { First utility programs launched } \\
\text { in late } 1990 \text { s }\end{array}$ \\
\hline Finland & $\begin{array}{l}\text { Market opened to large customers in } 1995, \\
\text { residential customers gained access without } \\
\text { incurring fees in } 1998\end{array}$ & Limited & $\begin{array}{l}\text { First competitive products } \\
\text { launched in late } 1990 \mathrm{~s}\end{array}$ \\
\hline France & $\begin{array}{l}\text { Undergoing restructuring, only large } \\
\text { customers have direct access to date. No } \\
\text { schedule has been set for residential access to } \\
\text { competitive suppliers. }\end{array}$ & Emerging & To be determined \\
\hline Germany & $\begin{array}{l}\text { Market opened to all customers in } 1998, \\
\text { competitive offerings available to residential } \\
\text { customers since } 1999 \text {. }\end{array}$ & Moderate & $\begin{array}{l}\text { First utility programs offered in } \\
\text { mid-1990s, first competitive } \\
\text { products launched in } 1998\end{array}$ \\
\hline Ireland & $\begin{array}{l}\text { Green electricity customers and large } \\
\text { customers have had access to competitive } \\
\text { suppliers since February } 2000\end{array}$ & Limited & $\begin{array}{l}\text { First competitive marketers } \\
\text { appeared in } 2000\end{array}$ \\
\hline Italy & $\begin{array}{l}\text { Undergoing restructuring, only large } \\
\text { customers have direct access to date. Plans for } \\
\text { smaller consumers under development. }\end{array}$ & Emerging & To be determined \\
\hline Japan & $\begin{array}{l}\text { Legislature is studying restructuring options, } \\
\text { but no firm plans to implement retail choice } \\
\text { currently }\end{array}$ & Limited & $\begin{array}{l}\text { First green power options } \\
\text { appeared in } 1999-2000\end{array}$ \\
\hline $\begin{array}{l}\text { The } \\
\text { Netherlands }\end{array}$ & $\begin{array}{l}\text { Large and mid-sized companies have retail } \\
\text { access, green electricity customers gained } \\
\text { retail access in July 2001, all residential } \\
\text { customers to have choice in } 2004\end{array}$ & High & $\begin{array}{l}\text { First utility programs formed in } \\
1995 \text {, all } 12 \text { utilities have } \\
\text { offered programs since } 1999\end{array}$ \\
\hline Norway & $\begin{array}{l}\text { Market opened to competition in 1991, all } \\
\text { customers were able to switch suppliers } \\
\text { without incurring fees by } 1995\end{array}$ & Emerging & $\begin{array}{l}\text { First competitive products } \\
\text { launched in late } 1990 \mathrm{~s}\end{array}$ \\
\hline Sweden & $\begin{array}{l}\text { Market opened to competition in 1996, all } \\
\text { customers were able to switch suppliers } \\
\text { without incurring fees by } 1999\end{array}$ & Moderate & $\begin{array}{l}\text { First green power products } \\
\text { appeared in } 1996 \text { with start of } \\
\text { competition }\end{array}$ \\
\hline Switzerland & $\begin{array}{l}\text { Restructuring plans still pending in legislature } \\
\text { (subject to referendum in fall of 2002). }\end{array}$ & Moderate & $\begin{array}{l}\text { First utility programs were } \\
\text { launched in mid-1990s }\end{array}$ \\
\hline $\begin{array}{l}\text { United } \\
\text { Kingdom }\end{array}$ & $\begin{array}{l}\text { Large customers gained direct access in } 1994 \\
\text { and residential customers gained retail access } \\
\text { by } 1999\end{array}$ & Moderate & $\begin{array}{l}\text { First utility programs launched } \\
\text { in } 1989 \text {, second generation of } \\
\text { products in late } 1990 \text { s. }\end{array}$ \\
\hline $\begin{array}{l}\text { United } \\
\text { States }\end{array}$ & $\begin{array}{l}\text { Partially open to competition; more than } 16 \\
\text { states have or are in the process of } \\
\text { implementing retail competition, } 7 \text { have } \\
\text { delayed restructuring, California has ceased } \\
\text { direct access }\end{array}$ & Moderate & $\begin{array}{l}\text { First utility programs launched } \\
\text { in early to mid-1990s, first } \\
\text { competitive products offered in } \\
1998\end{array}$ \\
\hline
\end{tabular}


Table 2: Power Market Statistics

\begin{tabular}{|c|c|c|c|c|c|c|}
\hline & $\begin{array}{r}\text { Total } \\
\text { Electricity } \\
\text { Customers } \\
\text { (million) }\end{array}$ & $\begin{array}{l}\text { Residential } \\
\text { Electricity } \\
\text { Customers } \\
\text { (million) }^{2}\end{array}$ & $\begin{array}{r}\text { Total } \\
\text { Electricity } \\
\text { Consumption } \\
(\text { Billion } \\
\mathrm{kWh})^{3}\end{array}$ & $\begin{array}{r}\text { Residential } \\
\text { Electricity } \\
\text { Consumption } \\
(\text { Billion } \\
\mathrm{kWh})^{4}\end{array}$ & $\begin{array}{r}\text { Residential } \\
\text { Cost of } \\
\text { Electricity } \\
\text { (U.S.\$/kWh) }\end{array}$ & $\begin{array}{r}\text { Total } \\
\text { Generating } \\
\text { Capacity } \\
(\text { Thousand } \\
\mathrm{MW})^{5} \\
\end{array}$ \\
\hline \multicolumn{7}{|l|}{ North America } \\
\hline Canada & 14.9 & 11.9 & 497.5 & 129.5 & 0.060 & 109.8 \\
\hline United States $^{6}$ & 126.0 & 101.4 & 3412.8 & 1193.4 & 0.083 & 785.9 \\
\hline \multicolumn{7}{|l|}{ Europe } \\
\hline Denmark & 2.9 & 2.3 & 35.0 & 22.0 & 0.207 & 12.5 \\
\hline Finland & 2.9 & 2.3 & 79.0 & 31.0 & 0.091 & 16.1 \\
\hline Germany & 43.5 & 34.8 & 495.2 & 130.5 & 0.152 & 107.8 \\
\hline Ireland & 1.5 & 1.2 & 18.4 & 6.4 & 0.117 & 4.2 \\
\hline The Netherlands & 7.2 & 5.8 & 97.8 & 20.8 & 0.132 & 14.2 \\
\hline Norway & 2.5 & 2.0 & 124.0 & 61.0 & 0.063 & 27.6 \\
\hline Sweden & 5.2 & 4.2 & 144.8 & 69.5 & 0.101 & 32.9 \\
\hline Switzerland & 3.8 & 3.0 & 51.9 & 15.1 & 0.131 & 14.6 \\
\hline United Kingdom & 27.3 & 21.8 & 333.0 & 109.6 & 0.117 & 69.9 \\
\hline \multicolumn{7}{|l|}{ Other } \\
\hline Australia & 8.7 & 7.5 & 178.3 & 46.5 & 0.080 & 37.9 \\
\hline Japan & 71.0 & 56.8 & 947.0 & 251.8 & 0.212 & 226.4 \\
\hline
\end{tabular}

${ }^{1}$ German Electricity Association, Electricity Market Germany 1999, Frankfurt, p. 65. Data for Sweden, Finland, Denmark, and Norway from the Swedish National Energy Administration, Electricity Market 2001, pp. 8, 26. Data for Australia as of June 2000 from Electricity Supply Association of Australia, Industry Data http://www.esaa.com.au/store/page.pl?id=1281. Japanese and Canadian figures estimated based on residential estimate, assuming residential customers are $80 \%$ of total.

${ }^{2}$ U.S. data from Energy Information Administration, Electricity Consumption and Expenditures in U.S. Households by End Uses and Census Region, 1997. Canadian data from Electric Power Generation, Transmission, and Distribution 1999, 57-202-XPB, Statistics Canada, 2001. It includes residential and agricultural customers.

http://www.eia.doe.gov/emeu/recs/byfuels/table3.html. Assumed residential customers are $80 \%$ of total based on actual ratio in U.S. Data for Australia from Electricity Supply Association of Australia, Industry Data http://www.esaa.com.au/store/page.pl?id=1281. Japanese data supplied by M. Ohbayashi.

${ }^{3}$ Energy Information Administration, International Energy Annual, Tables 6.2, 6.4.

http://www.eia.doe.gov/emeu/international/electric.html\#IntlConsumption Electric Power Annual, Volume 1, Table A4. Data for Sweden, Finland, Denmark, and Norway from Swedish National Energy Administration, Electricity Market 2001, pp. 8, 26.

${ }^{4}$ International Energy Agency, Electricity Information 2000 Edition. Data for Sweden, Finland, Denmark, and Norway from Swedish National Energy Administration, Electricity Market 2001, pp. 8, 26. Ireland assumed to be 35\% of total electricity consumption.

${ }^{5}$ Energy Information Administration, International Energy Annual, Tables 6.2, 6.4. Electric Power Annual, Volume 1, Table A4.

${ }^{6}$ U.S. Statistics from Energy Information Administration, Annual Electric Utility Report, Table 8 and U.S. Power Industry Summary Statistics, Table 2. http://www.eia.doe.gov/cneaf/electricity/epm/epmt02p1.html and Industry Capability by Fuel Source and Sector, Table 2

http://www.eia.doe.gov/cneaf/electricity/epav1/elecprod.html\#tab2 


\section{Australia}

\section{Power Industry Overview}

Most Australian states and territories are in the process of phasing in retail competition. Large commercial and industrial customers can already choose their energy suppliers in most states, while residential customers in Victoria and New South Wales began retail choice in January 2002. Some states are reconsidering or delaying deregulation. While most electric utilities were state-owned prior to deregulation, they are being split up and privatized as a result of market reforms. About $90 \%$ of Australia's electricity is generated from thermal plants that rely primarily on coal, with the rest supplied from renewable resources, mainly hydropower. ${ }^{3}$

\section{Green Power Marketing Activity}

Utilities first began to market green power to customers in Australia in the mid-1990s. Today, incumbent retail energy suppliers offer green power options in Victoria, New South Wales, Queensland, the Australian Capital Territory (ACT), South Australia, and Western Australia, giving more than $95 \%$ of the country's retail customers the option to purchase green power. ${ }^{4}$

\begin{tabular}{|l|l|c|c|c|l|}
\hline & Resources & $\begin{array}{c}\text { Estimated } \\
\text { Products } \\
(\#)\end{array}$ & $\begin{array}{c}\text { Estimated } \\
\text { Customers } \\
(\#)\end{array}$ & $\begin{array}{c}\text { Price } \\
\text { Premiums } \\
\phi / k W h\end{array}$ & Examples \\
\hline $\begin{array}{l}\text { Energy-based } \\
\text { products }\end{array}$ & $\begin{array}{l}\text { biomass, } \\
\text { wind, solar, } \\
\text { and hydro }\end{array}$ & $\sim 20$ & 57,000 & $\begin{array}{c}\sim \mathrm{A} 3-5 \\
(\mathrm{U} . \mathrm{S} .2-3)\end{array}$ & $\begin{array}{l}\text { PowerCor, Energy } \\
\text { Australia, Energex, } \\
\text { Ergon Energy }\end{array}$ \\
\hline $\begin{array}{l}\text { Contribution } \\
\text { programs }\end{array}$ & solar & 1 & 11,000 & $\mathrm{n} / \mathrm{a}$ & Integral Energy \\
\hline Total & & $\sim 20$ & 68,000 & & \\
\hline
\end{tabular}

Table 3: Classification of Green Power Products in Australia

In Australia, there are about 20 green power products available in the market, with about three-quarters of these accredited by the National Green Power Accreditation program (see Table 3). A few marketers recently began offering uncertified products, particularly to non-residential customers. ${ }^{5}$ In addition, one green power provider offers a contribution-based renewable energy product, through which customers can contribute to a fund to develop new renewables. Contribution programs have been phased out of the national accreditation program, because they have "proven less effective in the installation of new renewable generators," according to the Sustainable Energy Development Authority (SEDA). ${ }^{6}$

\footnotetext{
${ }^{3}$ Energy Information Administration (EIA) (2001a); NEMMCO (2001)

${ }^{4}$ Sustainable Energy Development Authority (SEDA) (2001a).

${ }^{5}$ Cribb and Saltman (2002).

${ }^{6}$ SEDA (2000a), p. 1 .
} 
Most energy-based products consist of biomass power blended with other renewable sources such as wind, solar, and hydro. Marketers typically offer customers the option of purchasing $50 \%$ or $100 \%$ of their power from renewable sources, with a few companies offering smaller purchase options, such as $10 \%$ or $25 \%$. Recently, suppliers have offered products with at least $70 \%$ new renewable energy content, which is a requirement of the national certification program. The requirement increased to $80 \%$ new renewable energy content as of 2002. Most residential green power products are priced $3 \mathrm{~A} \phi / \mathrm{kWh}$ to $5 \mathrm{~A} \notin / \mathrm{kWh}$ (U.S. 2 to $3 \notin / \mathrm{kWh}$ ) above standard electricity rates (potentially a $30 \%$ premium). Products are also typically available to business customers at negotiated quantities and rates.

\section{Consumer Response}

As of June 2001, about 57,000 customers were purchasing accredited green power products, including about 2,300 business customers. More than three-quarters of the green power sales were to customers in New South Wales and Queensland. Total sales of green energy were approximately 460 million $\mathrm{kWh}$ for the one-year period between July 2000 and June 2001, with business customers representing nearly half. Since 1997, when data first became available, green power sales have increased 10-fold. The number of customers has also climbed considerably during this period. For example, between 1999 and 2000 , the number of green power customers increased by more than $50 \%$. There was a slight dip in the number of customers participating in accredited programs in 2000/2001 - because the national accreditation program stopped certifying contribution programs in 2000, those customers were dropped from the totals (see Figure 1). Overall, green power customers currently represent nearly $1 \%$ of the residential electricity market. ${ }^{7}$

\section{Suppliers}

Three of the more successful green power marketers - Energy Australia (NSW), Powercor (Victoria), and ActewAGL - have obtained about 2-3\% of residential customers in their franchise service areas. ${ }^{8}$ These programs have been successful at least in part because of high-level institutional support and dedicated staff. Several marketers have successfully used telemarketing to obtain customers. Companies who provide regular newsletters of program updates to participants have also fared well. Overall, however, green power programs have not been marketed particularly aggressively. ${ }^{9}$ Two of the more successful companies are profiled below.

\footnotetext{
${ }^{7}$ SEDA (2000a); SEDA (2001a).

${ }^{8}$ SEDA (2001a).

${ }^{9}$ Cribb and Saltman (2002).
} 


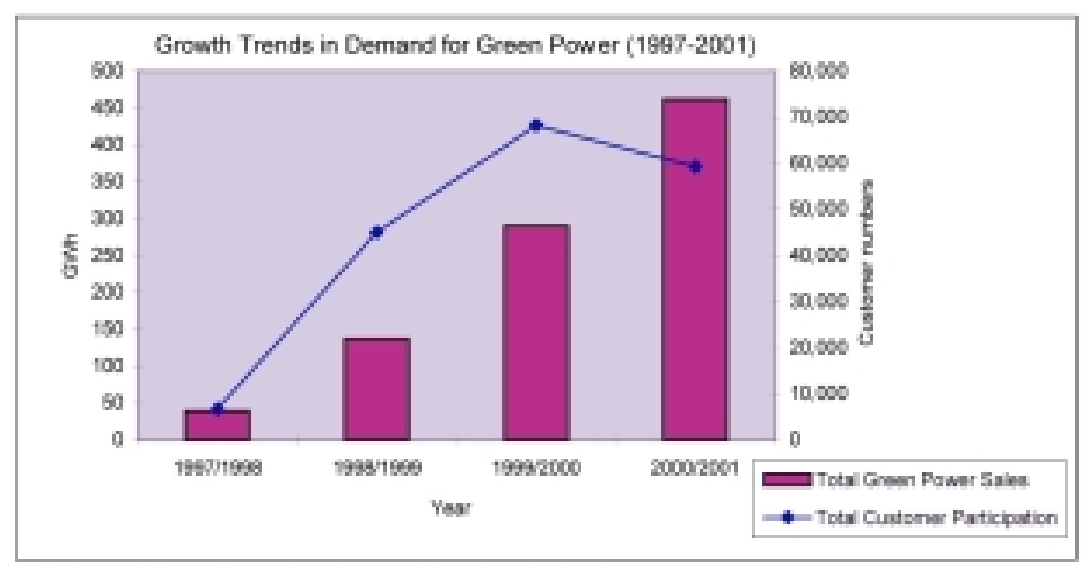

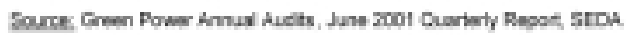

Figure 1: Growth Trends in Demand for Green Power in Australia

Energy Australia, a utility serving about 1.4 million customers in New South Wales, became one of the first utilities to market green power when it launched its Pure Energy ${ }^{10}$ program in 1996. This program allows residential customers to have $50 \%$ or $100 \%$ of their electricity supplied from renewable sources, such as biomass, hydro, wind, and solar. Business customers can elect to have any percentage of their electricity needs supplied from green resources. As of October 2000, residential customers could purchase $100 \%$ green power at a price premium of about $1.2 \mathrm{~A} \notin / \mathrm{kWh}(\sim \mathrm{U} . \mathrm{S} .0 .6 \notin / \mathrm{kWh})$. Power for the program is supplied from new and existing resources. The new resources include a $600-\mathrm{kW}$ wind turbine installed on Kooragang Island in the fall of 1997, a 200-kW solar system in New South Wales, about $6501-\mathrm{kW}$ photovoltaic systems installed at the Olympic Village in 2000, and new biomass projects in Lucas Heights and Belrose. As of June 2001, Energy Australia had sold about 54 million kWh of green power, which is equivalent to the consumption of about 32,000 average households. ${ }^{11}$ The program achieved early success as a result of a number of pilot marketing efforts, but since then marketing efforts have tapered off and growth has slowed. In fact, in 2001, the company ceased accepting new customers because it ran out of adequate supply to continue to comply with the new renewable certification requirements. ${ }^{12}$

ActewAGL is a privately and publicly held utility that provides electricity service to about 135,000 customers, including about 1,000 customers outside of its franchise service territory in the Australian Capital Territory. ActewAGL launched its Greenchoice ${ }^{13}$ green power program in March 1999. Under the program, residential customers could purchase $50 \%$ or $100 \%$ of their electricity from renewable sources, while business customers could also select a $25 \%$ purchase option. There were daily caps on the amount of green power

\footnotetext{
${ }^{10}$ http://www.energy.com.au/environment/pureenergy.asp, February 5, 2001.

${ }^{11}$ SEDA (2001b).

${ }^{12}$ Cribb and Saltman (2002).

${ }^{13} \mathrm{http}: / / \mathrm{www}$.actewagl.com.au/greenchoice, January 4, 2001.
} 
that could be purchased. ActewAGL now offers Greenchoice 10 and 15, under which the company will supply customers with $10 \mathrm{kWh}$ or $15 \mathrm{kWh}$ of electricity generated from renewable sources each day for a premium of $4.95 \mathrm{~A} \phi / \mathrm{kWh}(\sim \mathrm{U} . \mathrm{S} .3 \phi / \mathrm{kWh})$. The utility advertises the participation of business customers. Power for the program is primarily supplied from new biomass power plants fueled by bagasse, with the remainder supplied from new wind, micro hydro, and existing solar resources. As of June 2001, about 3,700 customers were participating in Greenchoice. The company has achieved a relatively high response rate by reaching customers in its relatively small service territory through television advertising, telemarketing and other direct marketing. ${ }^{14}$

As of June 2001, green power marketing has led to the development more than 100 new renewable projects with a combined capacity of nearly $200 \mathrm{MW}$, according to SEDA. An additional $400 \mathrm{MW}$ of capacity is planned for 2002. Under the rules of the accreditation program, energy sales from accredited green power products cannot be used to meet Australia's renewable energy purchase obligation. The strict requirement for new renewables is expected to continue to spur development over time. ${ }^{15}$

\section{Certification}

The National Green Power Accreditation Program, ${ }^{16}$ established in May 2000, certifies both green power products and generators. The program grew out of the New South Wales accreditation program developed by SEDA in 1997. The national program is now offered through a collaborative effort of government agencies in New South Wales (NSW), Victoria, Queensland, South Australia, and the Australian Capital Territory (ACT) and managed by SEDA. Eligible renewable resources for accredited products include solar, wind, biomass (excluding municipal solid waste), geothermal, hydro (except projects that involve construction of new dams), and wave or tidal power. Generators can receive accreditation if they reduce greenhouse gas emissions, offer other net environmental benefits, and generate most of their electricity from renewable sources. As of 2002, certified providers are required to supply $80 \%$ of their green power from new renewable sources (some suppliers are given two years to meet the requirement).

Certified green power sales must be in excess of renewable power purchased to meet the national renewable energy purchase obligation. As of April 2002, there are more than 200 new and existing accredited renewable energy generating facilities eligible to supply power for accredited products. ${ }^{17}$

\section{Policies Affecting the Green Power Market}

As part of its overall strategy for reducing greenhouse gas emissions, the Australian government offers a variety of support mechanisms for renewable resources. Incentives include rebates for photovoltaic systems, commercialization grants, and venture capital for innovative renewable energy companies. In addition, the 2000 Renewable Energy

\footnotetext{
${ }^{14}$ Cribb and Saltman (2002).

${ }^{15}$ SEDA (2000b); Cribb (2002).

${ }^{16}$ See the accreditation program Web site at http://www.greenpower.com.au/steering.shtml.

${ }^{17}$ SEDA (2001c).
} 
(Electricity) Act requires wholesale electricity purchasers to support an additional 9,500 gigawatt-hours $(\mathrm{GWh})$ of electricity annually from renewable sources by 2010 , which is expected to represent nearly $2 \%$ of total generation. In the first year of the obligation (2001), suppliers will be required to collectively purchase $300 \mathrm{GWh}$ from renewable power sources, with the level increasing to $1,100 \mathrm{GWh}$ in 2002 . The requirement increases annually until 2010 when it becomes fixed for each of the next 10 years. To implement the purchase requirement, the government established the Office of the Renewable Energy Regulator to issue renewable certificates and oversee trading. Eligible renewable energy facilities began earning certificates on the basis of their renewable generation on April 1, 2001 (not retrospectively) ${ }^{18}$ The impact of the purchase obligation on the green power market is uncertain thus far. However, early indications suggest that it has not had a negative effect - according to SEDA, green power sales were up 50\% in $2000 / 01$ after the obligation was introduced. The obligation could have a positive impact on the market if economies of scale are achieved by expanding new renewable projects to meet both needs. The certificate-trading system could also make it easier for new market entrants to obtain supplies. On the other hand, consumer demand for green energy could decline if customers feel that renewable energy development is already adequately supported under this policy.

\section{Outlook}

There are a relatively large number of green power marketers, and nearly all customers in Australia have access to green power. The Australian green power market has grown steadily during the past several years, but market penetration levels are still relatively modest at about $1 \%$. The most successful utility green power programs have achieved participation rates of $2-3 \%$ of the customers in their franchise service territories. The government-run certification program has played a significant role in shaping green power product offerings, particularly with respect to new renewable energy content. The program's aggressive new renewable standard is stimulating growth in renewable energy capacity and should continue to do so over time. Based on recent growth patterns, it is likely that participation in green power programs will also continue to climb. It remains to be seen what impact the government-imposed renewable purchase obligation will have on consumer participation in voluntary programs. At the same time, the certificatetrading program established to implement the purchase obligation could facilitate green power transactions and encourage further development of the market.

\footnotetext{
${ }^{18}$ Office of the Renewable Energy Regulator (2001).
} 


\section{Canada}

\section{Power Market Overview}

Alberta was the first province in Canada to open its electricity market to competition. By 2001 , all retail electricity customers had the ability to switch suppliers. Ontario is also in the process of restructuring and, although retail competition has been delayed, it is scheduled to begin in May 2002. Several other provinces have implemented wholesale competition, but have no plans to expand it to the retail sector. Canada obtains more than $60 \%$ of its electricity from large hydroelectric sources, with the remainder supplied from coal (17\%), nuclear (15\%), oil and gas $(7 \%)$, and biomass $(1 \%)$. It is a net exporter of electricity. ${ }^{19}$

\section{Green Power Marketing Activity}

Until recently, the Canadian market for green power has been largely limited to Alberta, the first province to institute retail competition. The first products were introduced in the late 1990s by incumbent utilities, Epcor and Enmax. Currently, these companies collectively serve about 6,000 green power customers. In addition, Vision Quest, which supplies wind power to one of the utilities, also offers a wind power product to retail customers in other parts of the province.

Recently, several marketers have launched green power products or announced plans to offer green power to customers in Ontario, where retail competition is set to begin shortly. For example, Ontario Power Generation is offering green power to large commercial and industrial customers and, at the wholesale level, to distribution utilities. ${ }^{20}$ It offers three green power products, which differ in respect to the fraction of power generated from certified renewable facilities commissioned before and after 1991. In early 2001, the company established an operating unit called "Evergreen Energy" to develop and supply power from renewable sources. Currently, it is developing a $10 \mathrm{MW}$ wind project along Lake Huron in Ontario to add to its green power mix, which consists primarily of small hydro. In addition, Toronto Hydro Energy Services recently announced a green power option for residential and business customers, called Citisource Green Power ${ }^{21}$. The product, which will be available to Ontario customers when the market opens to competition, will be sold in blocks and supplied from wind and certified hydro resources. The company is teaming with the Toronto Renewable Energy Cooperative to build two wind turbines on Toronto's waterfront, which are expected to be operational by the fall of 2002. Other existing green power marketers have indicated interest in offering green power options when the market opens.

\footnotetext{
${ }^{19}$ Natural Resources Canada (1999).

${ }^{20} \mathrm{http}: / /$ www.opgdirect.com/content/secure/serving_needs/greenpower/index.asp, accessed April 2002.

${ }^{21}$ http://micro.newswire.ca/releases/March2002/27/c4780.html/20298-0, accessed April 2002.
} 
In areas without retail access, at least two marketers recently began offering green power products and another announced its intention to offer a product in the fall of $2002 .^{22} \mathrm{In}$ April 2002, SaskPower, a municipal utility in Saskatchewan, began offering a wind power option to residential and business customers. The power comes from two wind farms with a combined capacity of nearly $17 \mathrm{MW}$, much of which is supplying the power needs of government facilities in the province. In late 2001, Maritime Electric, a utility in Prince Edward Island, launched a green power product, which is supplied from a new 5.2 MW wind project. And in British Columbia, BC Hydro recently announced its intention to offer green power to commercial and industrial customers in the fall of $2002 .{ }^{23}$ Wind power projects are also being developed in Nova Scotia and Newfoundland, setting the stage for possible green power marketing efforts in those regions. ${ }^{24}$

Price premiums for green power products range from $3.5 \mathrm{C} \phi / \mathrm{kWh}$ to $9.8 \mathrm{C} \notin / \mathrm{kWh}$ ( $\sim \mathrm{U} . \mathrm{S} .2$ to $6 \notin / \mathrm{kWh})$. Most of the products are supplied primarily with wind power, but at least one marketer offers a blend of biomass, solar, and wind. Table 4 summarizes the green power products offered in Canada to date.

\begin{tabular}{|c|c|c|c|c|c|}
\hline & $\begin{array}{l}\text { Estimated } \\
\text { Marketers/ } \\
\text { Utilities (\#) }\end{array}$ & $\begin{array}{c}\text { Estimated } \\
\text { Customers } \\
\text { (\#) }\end{array}$ & $\begin{array}{c}\text { Price } \\
\text { Premiums } \\
\phi / k W h\end{array}$ & Resources & Examples \\
\hline $\begin{array}{l}\text { Competitive } \\
\text { Markets }\end{array}$ & $\sim 4$ & $\sim 6,000$ & $\begin{array}{c}6.6-9.8 \\
(\sim \text { U.S. 4-6) }\end{array}$ & $\begin{array}{l}\text { Wind, small } \\
\text { hydro, } \\
\text { biomass }\end{array}$ & $\begin{array}{l}\text { Epcor, Enmax, } \\
\text { Vision Quest, } \\
\text { Ontario Power } \\
\text { Generation }\end{array}$ \\
\hline $\begin{array}{l}\text { Regulated } \\
\text { Markets }\end{array}$ & 2 & $<700$ & $\begin{array}{c}3.5 \\
(\sim \text { U.S. 2) }\end{array}$ & Wind & $\begin{array}{l}\text { SaskPower, } \\
\text { Maritime } \\
\text { Electric }\end{array}$ \\
\hline Total & $\sim 6$ & $>6,500$ & & & \\
\hline
\end{tabular}

Table 4: Classification of Green Power Products in Canada

\section{Suppliers}

Two of the leading green power suppliers (and those that have been active the longest) are Enmax and Epcor, both incumbent utilities serving customers in Alberta. Enmax Corporation, a wholly owned subsidiary of the City of Calgary, was the first Canadian company to offer customers the opportunity to meet a portion of their electricity use with wind energy when it launched its Greenmax program in 1998. Under the program, customers can purchase wind power at monthly premiums of $\mathrm{C} \$ 5, \$ 10$, or $\$ 15$. An average customer paying $C \$ 15$ per month would receive $250 \mathrm{kWh}$ of wind power, or about $45 \%$ of his/her monthly consumption. In 2000 , the company relaunched the

\footnotetext{
${ }^{22}$ In recent years, two municipal utilities - Cambridge and North Dumfries Hydro of Ontario and West Kootenay Power of British Columbia-supplied a small number of customers in British Columbia and Ontario with green power, but are no longer offering green power products

${ }^{23}$ Dogterom (2002).

${ }^{24}$ Raynolds and Pape (2000); Pape (2001).
} 
program and participation grew by about $150 \%$ to about 2,000 customers by the year's end. As part of a new marketing strategy, the company teamed with local retailers to offer Greenmax's customers special discounts. Enmax has installed $34 \mathrm{MW}$ of wind to supply the program and is looking to install additional resources to allow the program to grow. About 3,200 of the company's 325,000 customers, or about $1 \%$, were participating in Greenmax as of late 2001. Non-residential customers also participate and currently purchase about $90 \%$ of the available power. ${ }^{25}$ Enmax plans to expand the program to other markets as they open for competition. Greenmax is EcoLogo-certified through the Environmental Choice program. ${ }^{26}$

Epcor Energy Services, an Alberta-based electric utility that serves more than 270,000 customers in Edmonton, began offering its EcoPack green power product in July 1999. Customers in the program can choose to purchase $10,20,50$, or $100 \%$ of their power from renewable sources. The $10 \%$ option is offered for an extra C\$5 ( U.S. \$3) per month and the $100 \%$ option is C $\$ 40$ ( U.S. \$25), which represents a premium of about $\mathrm{C} 7 \notin / \mathrm{kWh}(\sim \mathrm{U} . \mathrm{S} .4 \varnothing / \mathrm{kWh})$ for an average consumer using $550-\mathrm{kWh}$ per month. The power is supplied from a biomass facility that burns waste wood from sawmills, a 12.75 MW run-of-the river hydro facility, a $13 \mathrm{~kW}$ solar photovoltaic system, and a 900-kW wind turbine located on the Peigan Indian Reservation in southern Alberta. EPCOR's EcoPack product is EcoLogo-certified by the Environmental Choice program. According to the company, more than 3,000 customers were participating in the program as of June $2001 .^{27}$

\section{Certification}

The national Environmental Choice Program ${ }^{28}$ certifies green power distributors and generators. Originally created by the Canadian government in 1988 to encourage demand for and supply of a wide range of environmentally responsible products, the program is now managed by a private firm. In 1996, the group developed interim criteria and began certifying alternative electric generating sources. Subsequently, more detailed standards for low-impact renewable electricity were developed through a consensus-based process. Under the current standards, certified products can include power generated from wind, solar, hydro, biomass, and biogas facilities. Use of the logo is available to renewable generating facilities, marketers offering bundled green power products, and users who meet the standards and pay licensing fees. In December 2001, Environmental Choice issued new draft guidelines which contained significant changes regarding the ownership of environmental attributes and the percentage of new renewables required in certified products. Following a public comment period, new guidelines will be issued. As of April 2002, 5 green power marketers and 31 renewable power suppliers had been certified under the program.

\footnotetext{
${ }^{25}$ Howland (2002).

${ }^{26}$ Enmax (2000).

${ }^{27}$ Epcor $(2000,2001)$.

${ }^{28}$ See the Environmental Choice Web site at http://www.environmentalchoice.com/products.cfm?Cat=1.
} 


\section{Policies Affecting the Green Power Market}

Canada provides some support for the development of renewable resources as part of its overall greenhouse gas mitigation strategy. ${ }^{29}$ In addition, the federal government recently adopted wind energy production tax credits for projects commissioned between March 31, 2002 and April 1,2007. The incentives, which are paid for 10 years, start at C1.2ф/kWh ( U.S. $0.8 \notin / \mathrm{kWh})$ and decline to C0.8ф/kWh ( U.S. $0.5 \notin / \mathrm{kWh})$ by the fifth year. ${ }^{30}$

Other government activities that have directly affected the green power market include the accreditation of green power products and suppliers as discussed above, requirements for fuel mix disclosure, and government green power purchases. ${ }^{31}$ At least one province (Ontario) is developing a fuel mix disclosure requirement to provide consumers with information about the impacts of resources used to generate electricity. With respect to purchasing, two government agencies - Natural Resources Canada and Environment Canada - have committed to purchase between $15 \%$ and $20 \%$ of their electricity from renewable sources by $2010 .^{32}$ In 1997 , the two agencies purchased wind energy for Alberta-based facilities, which encouraged Enmax to launch its Greenmax offering to residential and commercial customers. More recently, the Natural Resources Canada Minister stimulated the Saskatchewan market by committing $\$ 12.4$ million over 10 years to SaskPower for wind power to supply government facilities in the province. ${ }^{33}$ The agencies are also purchasing green power in Prince Edward Island. In addition, provincial and municipal governments have purchased or announced plans to purchase green power. Relative to other measures, government purchases have been the most effective in spurring the development of the Canadian green power market.

\section{Outlook}

Although there has been an increase in the amount of green power marketing activity in Canada recently, there are still a relatively small number of utilities and marketers offering products. Until recently, most of the activity centered around Alberta, the first market to open to competition. In that region, two incumbent utilities have managed to subscribe several thousand customers, representing about $1 \%$ of their respective customer bases. Marketing efforts are now beginning to spread to other regions. New markets are developing in Saskatchewan and Prince Edward Island, aided by government green power purchases. Growth is also expected in the Ontario market, where several marketers have begun or are planning to offer green power when competition begins.

\footnotetext{
${ }^{29}$ A portion of the government's climate change funds support research and development, subsidies, and market incentives for renewables. The federal government also provides a $25 \%$ capital cost rebate for solar and biomass thermal technologies and tax credits for a portion of predevelopment expenses associated with renewable energy facilities (Pape et al., 1999).

${ }^{30}$ Financial Times (2002).

${ }^{31}$ Pape, Hornung, and Cowan (1999).

${ }^{32}$ Canadian Wind Energy Association (1999).

${ }^{33}$ Natural Resources Canada (2000).
} 


\section{Finland}

\section{Power Industry Overview}

The Finnish electricity market was opened to large electricity consumers starting in November 1995 and to all consumers in January 1997. In late 1998, small customers were exempt from a requirement to install hourly meters, which enabled them to switch suppliers without incurring costs. Electricity prices have fallen somewhat as a result of competition, with the total cost of electricity reduced by an average of $1.1 \%$ in 2000 . For some small consumers, list prices fell by as much as $15-24 \% .{ }^{34}$ The primary resources used to generate electricity in Finland are fossil fuels (37\%), nuclear (32\%), hydropower (21\%), and biofuels (9\%). Finland imports a relatively large amount of electricity from neighboring countries; in 2000, imports represented about $15 \%$ of total electricity consumption. ${ }^{35}$ Currently, average residential electricity prices are about $50 \mathrm{p} / \mathrm{kWh}(\sim$ U.S. $8.4 \notin / \mathrm{kWh}$ ), including taxes, the lowest among all of the Nordic countries. ${ }^{36}$

\section{Green Power Marketing Activity}

Currently, there are at least 30 companies offering green power in Finland. Some green power providers offer more than one product, such as a wind power option and a blend of certified renewables. More than three-quarters of all products feature wind power. A number of suppliers offer power generated from biomass resources, such as wood waste. Helsinki Energy and several other suppliers offer green power in 1,000 kWh blocks, which have been popular among customers. Table 5 provides summary data on the green power products offered in Finland.

According to a survey conducted by the Department of Marketing at the University of Vaasa, the number of green power customers increased by about $60 \%$ between 1999 and 2000. As of May 2001, about 6,000 customers, including about 300 small and mid-sized nonresidential customers, were purchasing some form of green power. ${ }^{37}$ Only about onethird of the customers switched electricity providers to purchase green power. Of the total, about 2,000 were purchasing certified products. Since then, the number of customers purchasing certified green power products are estimated to have grown to about 4,000 (as of early 2002), bringing the total number of customers to about $8,000 .^{38}$

Collectively, sales of certified green power represented about $0.2 \%$ of all electricity sold (about 78 TWh) in Finland as of the spring of 2001. Data on sales of uncertified green energy are not available.

Price premiums for green power have been modest, with many products priced below standard offer service. On average, residential consumers have been able to purchase

\footnotetext{
${ }^{34}$ Finnish Energy Market Authority (2001).

${ }^{35}$ Swedish National Energy Administration (2001).

${ }^{36}$ Finnish Energy Industries Federation (2001).

${ }^{37}$ University of Vaasa (2001).

${ }^{38}$ Tepponen (2002).
} 
green power at a discount of about $2 \mathrm{p} / \mathrm{kWh}$ to $5 \mathrm{p} / \mathrm{kWh}(\sim \mathrm{U} . \mathrm{S} .0 .3$ to $0.8 \varnothing / \mathrm{kWh})$ compared to the cost of standard offer service. Of those products offered at a premium, the highest premiums reached about $4 \mathrm{p} / \mathrm{kWh}(\sim$ U.S. $0.6 \notin / \mathrm{kWh})$ for certified renewable energy blends and $6 \mathrm{p} / \mathrm{kWh}(\sim \mathrm{U} . \mathrm{S} .0 .8 \notin / \mathrm{kWh})$ for wind power. The largest discounts offered for certified green power blends have been about 10 p/kWh ( U.S. $1.5 \varnothing / \mathrm{kWh}){ }^{39}$

Despite the low price premiums, green power sales have been relatively low. According to the University of Vaasa study, some of the factors that have limited the adoption of green power in Finland are that consumers inaccurately perceive the cost of green power to be high, they lack an understanding of what green electricity is and how to purchase it, and marketers have not adequately marketed green power products.

\begin{tabular}{|c|c|c|c|c|}
\hline Product Category & $\begin{array}{l}\text { Estimated } \\
\text { Products } \\
\text { (\#) }\end{array}$ & $\begin{array}{l}\text { Estimated } \\
\text { Customers } \\
\text { (\#) }\end{array}$ & Premiums & Examples \\
\hline $\begin{array}{l}\text { Certified products } \\
\text { (often renewable } \\
\text { blends) }\end{array}$ & $>20$ & $\sim 4000$ & $\begin{array}{c}0-3.8 \mathrm{p} / \mathrm{kWh} \\
\text { (U.S. 0-0.6 } / \mathrm{kWh} \text { ) }\end{array}$ & $\begin{array}{l}\text { Etelä-Savon Energia, } \\
\text { Joutsenon Energia, } \\
\text { Kainuun Sähkö }\end{array}$ \\
\hline $\begin{array}{l}\text { Uncertified } \\
\text { products } \\
\text { (typically wind) }\end{array}$ & $\sim 20$ & $>4000$ & $\begin{array}{c}0-5.6 \mathrm{p} / \mathrm{kWh} \\
\text { (U.S. } 0-0.8 \notin / \mathrm{kWh} \text { ) }\end{array}$ & $\begin{array}{l}\text { Helsingin Energia, } \\
\text { Vantaan Energia Oy }\end{array}$ \\
\hline Total & $\sim 40$ & $>8000$ & & \\
\hline
\end{tabular}

Table 5: Green Power Product Offerings in Finland

\section{Certification}

The Finnish Association for Nature Conservation certifies more than 20 retail green power products under its Norppa eco-labeling program. ${ }^{40}$ The current program criteria, which will remain in effect through the end of 2003, allow the following renewable resources to be eligible for certification: biomass (excluding municipal solid waste), solar, wind, and hydropower constructed prior to 1996. To become certified, hydro facilities must prepare an action plan and take steps to mitigate environmental impacts to the affected waterway. In addition, plants that co-fire biomass with other fuels must reduce their carbon dioxide emissions over time. Companies marketing certified green power products are expected to support the development of new renewable projects (except in the case of hydro). The program requires suppliers to undergo annual audits to verify renewable energy purchases and sales. ${ }^{41}$

\section{Policies Affecting the Green Power Market}

Finland has a number of subsidies in place to support the development of renewable energy facilities. New renewable projects are eligible for grants equivalent of between

\footnotetext{
${ }^{39}$ University of Vaasa (2001).

${ }^{40}$ For more information, see http://www.sll.fi/energia/newsinbrief.html.

${ }^{41}$ Finnish Association for Nature Conservation (1999).
} 
$10 \%$ and $35 \%$ of the project's investment costs. In addition, production incentives are available for small hydro facilities, peat-fired CHP projects, and power plants fueled by wood or waste gases from metallurgical processes. Larger production incentives (equivalent to the electricity tax) are available for wind projects. ${ }^{42}$

\section{Outlook}

The Finnish green power market has been relatively active in terms of the number of marketers offering green power. However, customer response has been modest to date, with only 6,000 customers purchasing green power. Further, green power sales represent only about $0.2 \%$ of total electricity sales. Although the total number of green power customers is modest, it has grown steadily during the past two years. A lack of awareness on the part of consumers concerning the availability of green power products, the cost, and the purchase process have been cited as some of the most significant barriers to market penetration to date. In the future, at least modest growth in green power sales is likely, given that there are a relatively large number of marketers and many offer green power products that cost less than conventional electricity service.

\footnotetext{
${ }^{42}$ Swedish National Energy Administration (2001).
} 


\section{Germany}

\section{Power Industry Overview}

The German electricity market was opened to competition in April 1998. Because the new Energy Industry Law was not accompanied by detailed rules regarding grid access, transmission charges, and other important items, competition was slow to materialize. Industrial customers negotiated lower rates or switched to competitive suppliers early on, but it was not until August 1999 that the first significant retail offerings appeared in the market. Even today, relatively few customers have switched to alternative suppliers. Another factor contributing to the slow rate of switching in the retail market is the ongoing consolidation of the industry. As a result of recent mergers and acquisitions, there are now only four national electricity companies, with the two largest-E.On and RWE - controlling two-thirds of the country's power generation assets. The fuel mix in Germany is dominated by coal (53\%) and nuclear (33\%), with renewables (primarily large hydro) accounting for about $7 \%$ of electricity generation. The fastest growing resource in recent years has been wind energy, which has increased from about 2,900 MW to $8,800 \mathrm{MW}$ in just four years and now accounts for about 3.3\% of electricity generation. ${ }^{43}$ About $7 \%$ of electricity is generated as combined-heat and power (CHP), including 1,400 MW of small-scale projects $(<10 \mathrm{MW}) .{ }^{44}$ Because of the high overall efficiency (typically more than $80 \%$ of primary energy is converted into electricity and useful heat), CHP is considered green by some German marketers and product certifiers.

\section{Green Power Marketing Activity}

Utilities were the first to offer green power options to customers, with the launch of the first green pricing programs in the mid-1990s. Following the introduction of competition in 1998, a number of green power marketers introduced products, while incumbent utilities repositioned their programs for the newly competitive market environment. Today, more than 135 marketers supply green power to an estimated 325,000 customers in Germany. Three out of four green power customers buy $100 \%$ hydropower products offered by one of two companies, Naturenergie or E.On. About 95 of the 900 municipal utilities in Germany offer one or more green power products. In addition, a number of competitive marketers, including subsidiaries of existing utilities, such as Naturenergie, as well as start-ups with roots in the environmental community, such as Naturstrom, Lichtblick, and Greenpeace Energy, offer green power.

German green power products can be divided into three general categories: pure large hydro, blends of renewables and cogeneration or combined heat and power (CHP), and $100 \%$ renewable energy products (see Table 6). Most customers have selected the pure hydropower products, which are supplied from existing large-scale plants. Initially, marketers priced these products below generic electricity, although more recently they have been offered as premium products. A number of marketers have offered blends of renewables and cleaner electricity. Typically, these have been $50 \%$ to $80 \%$ renewable

\footnotetext{
${ }^{43}$ Hall (2001).

${ }^{44}$ Traube and Schulz (2000).
} 
with the remainder of the power supplied from gas-fired CHP plants that are cleaner and more efficient than traditional coal plants. Some of these products have included new renewable resources. Most marketers offer $100 \%$ renewable products that are typically not more than $75 \%$ large hydro. These generally include a percentage of power from new renewable sources and demand the highest price premiums.

\begin{tabular}{|c|c|c|c|c|c|c|}
\hline $\begin{array}{l}\text { Product } \\
\text { Category }\end{array}$ & Fuel mix & Certification & $\begin{array}{c}\text { Price } \\
\text { Premium }\end{array}$ & $\begin{array}{c}\text { Estimated } \\
\text { Customers } \\
\text { (\#) }\end{array}$ & $\begin{array}{l}\text { Estimated } \\
\text { Products } \\
\quad \text { (\#) }\end{array}$ & Examples \\
\hline $\begin{array}{l}\text { Large } \\
\text { Hydro }\end{array}$ & $\begin{array}{l}\text { Pure hydro, } \\
\text { mostly } \\
\text { existing } \\
\text { large-scale }\end{array}$ & TÜV EE02 & $5-10 \%$ & 250,000 & 3 & $\begin{array}{l}\text { E.On } \\
\text { Aquapower, } \\
\text { NaturEnergie } \\
\text { Silber }\end{array}$ \\
\hline $\begin{array}{l}\text { Cogen and } \\
\text { Renewable } \\
\text { Blends }\end{array}$ & $\begin{array}{l}\text { Typically } 20- \\
50 \% \text { fossil } \\
\text { cogeneration, } \\
50-80 \% \\
\text { renewables, } \\
\text { some new }\end{array}$ & $\begin{array}{l}\text { OK power, } \\
\text { TÜV UE01 }\end{array}$ & $15-35 \%$ & 55,000 & 8 & $\begin{array}{l}\text { Lichtblick, } \\
\text { Greenpeace } \\
\text { energy, HEAG } \\
\text { NaturPur Light }\end{array}$ \\
\hline $\begin{array}{l}100 \% \\
\text { Renewable }\end{array}$ & $\begin{array}{l}100 \% \\
\text { renewables, } \\
\text { some new, } \\
\text { maximum } \\
75 \% \text { hydro }\end{array}$ & $\begin{array}{l}\text { OK power, } \\
\text { Grüner } \\
\text { Strom } \\
\text { Label, TÜV } \\
\text { EE01 }\end{array}$ & $10-40 \%$ & 20,000 & $\sim 125$ & $\begin{array}{l}\text { NaturEnergie } \\
\text { Gold, RWE } \\
\text { avanza comfort } \\
\text { Oeko, BEWAG } \\
\text { OekoPur, } \\
\text { Naturstrom }\end{array}$ \\
\hline Total & & & & $\sim 325,000$ & $\sim 136$ & \\
\hline
\end{tabular}

Table 6: Classification of German Green Power Products

\section{Pricing}

German green power products are typically priced at premiums ranging from $10-30 \%$ of the total electricity price. Figure 2 compares the premiums for 29 nationally marketed green power products to the average of 32 major national generic power products. ${ }^{45}$ Because pricing structures differ with respect to fixed fees and per $\mathrm{kWh}$ adders, the comparison is based on the total annual cost for a four-person household consuming $4,000 \mathrm{kWh}$. The lowest-priced green power product, offered by LichtBlick, is only $6.7 \%$ more expensive than the average conventional electricity product, whereas the most expensive green power product is priced at almost a $40 \%$ premium. On average, green power products cost $22 \%$ more than conventional power products.

\footnotetext{
${ }^{45}$ Our calculation is based on information provided at www.stromtarife.de, an independent consumer information service maintained by the University of Münster's International Economic Forum for Renewable Energies (IWR). Prices are as of October 1, 2001. Utilities or marketers that offer their products only in their own region and not nationwide are not included.
} 


\section{$\underline{\text { Suppliers }}$}

The leading green power supplier, NaturEnergie entered the market in 1998, before any of the generic power marketers. The company, which is a fully owned subsidiary of two utilities, KWR and KWL, initially marketed a product supplied from existing hydropower and new photovoltaics. Through its early marketing campaign, NaturEnergie signed up about 1,000 customers by the summer of 1999. Later that year, it dramatically increased its customers when its sister company, EnergieDienst $\mathrm{GmbH}$, a regional distributor serving 150,000 customers in southwest Germany, switched all of its customers to hydropower unless they actively selected another product. Customers were automatically switched to a product called NaturEnergie Silber supplied from the company's existing large hydropower plants and priced $10 \%$ below previous rates. Customers could also opt to switch to a premium green power product, NaturEnergie Gold, supplied from renewable resources including hydro, wind, and PV with $30 \%$ of the power generated from new renewables. This product was priced at a $25 \%$ premium above the previous rate. Finally, customers could select a conventional power product generated primarily from coal and nuclear plants priced at about a $20 \%$ discount to the original rates. After two months, about $5 \%$ of the customers had actively switched to the discount power product or to another supplier, giving the company a reported 142,000 green power customers. NaturEnergie recently retreated from its national marketing campaign and is concentrating again on customers in the KWR and KWL service territories.

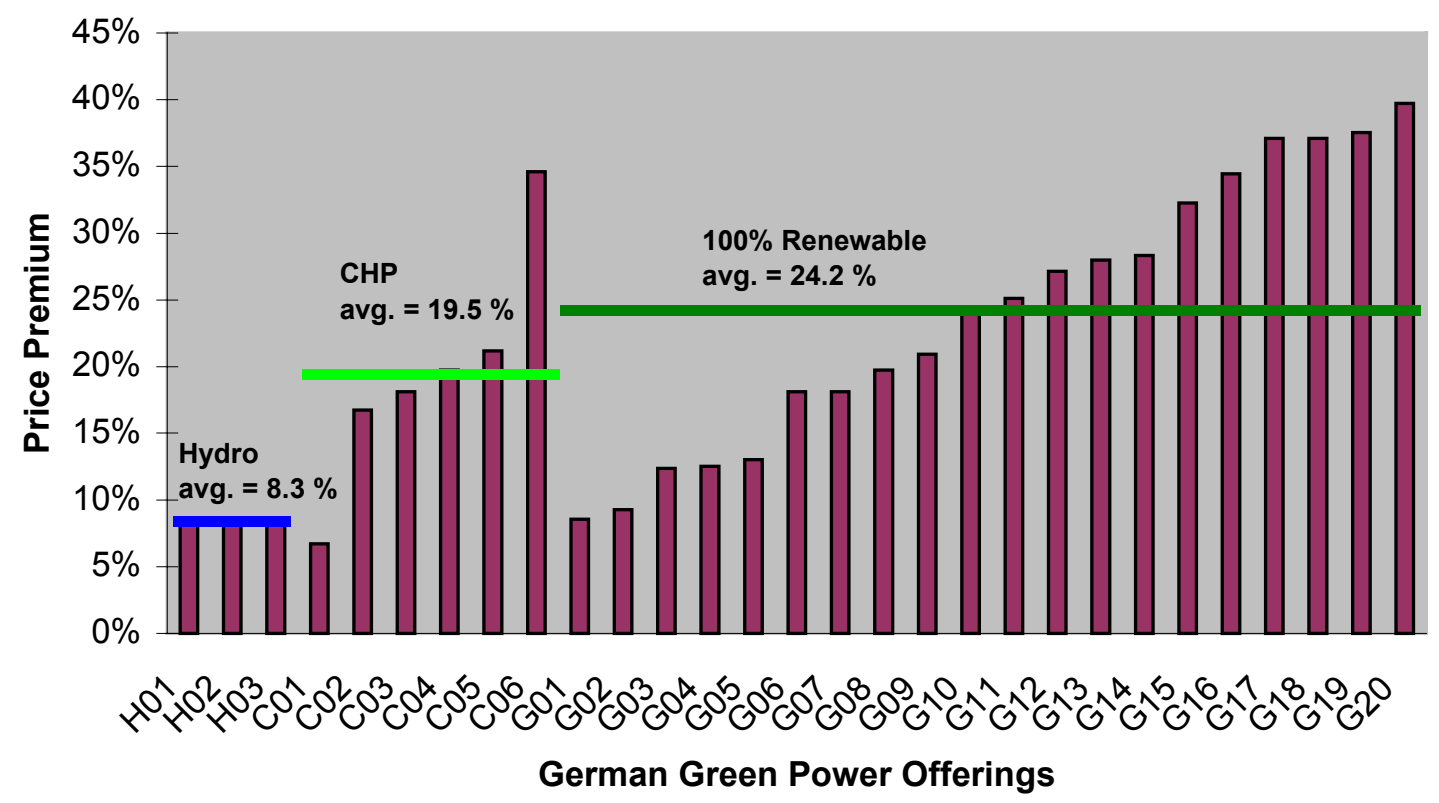

Figure 2: Price Premiums for Green Power Products in Germany ${ }^{46}$

\footnotetext{
${ }^{46}$ Authors' own calculations, data: www.stromtarife.de . In absolute terms, the average annual cost for $4,000 \mathrm{kWh}$ of conventional power is 660.79 euros, for hydro products 650.82 euros, for CHP products 718.09 euros, and for $100 \%$ renewable power products 746.12 euros.
} 
The other major hydropower marketer in Germany is E.On, which claims to have about 84,000 customers. Most of these customers are buying its pure hydropower product, Aquapower. Initially, the company heavily marketed Aquapower and priced it below standard rates. Recently, however, the company tried to reposition Aquapower as a premium product, charging $8 \%$ more than for its generic power product. The move has led to a notable slowdown in consumer interest. At the same time, E. On launched two additional products - NaturPower, a blend of hydro (75\%), wind (20\%), and biogas (5\%); and MixPower, through which customers can choose the fuel mix from a wide range of renewable and non-renewable sources using an interactive Web site. ${ }^{47}$

Besides the two largest green power suppliers, there are several green power marketers with about 10,000 to 50,000 customers. LichtBlick GmbH, a start-up formed by German entrepreneurs with involvement of a former Greenpeace manager, is the third largest green power supplier, with about 45,000 customers buying a product that consists of $75 \%$ renewables (mainly hydro, but some wind and biomass) and $25 \%$ efficient fossil cogeneration. LichtBlick recently increased its customer base substantially by teaming with Deutsche Post to sign up electricity customers at post offices. Greenpeace also formed an electric cooperative named Greenpeace energy and has signed up about 12,000 customers for a product that consists of $80 \%$ renewable resources including some PV and $20 \%$ cogeneration. Naturstrom AG is another start-up with roots in the environmental community that has signed up about 9,500 customers. Other start-ups, such as Oekostrom Handels AG (now P\&T Technology AG) and unit energy AG, recently exited the retail market to refocus on renewable energy generation.

A number of municipal utilities also have green power offerings and have subscribed several hundred to a few thousand households. ASEW, a subsidiary of the German association of municipal utilities, designed a product called Energreen, which is offered by several of its member utilities.

\section{Certification}

There are three competing certification programs in Germany: Grüner Strom, OK-Power, and TÜV. The Grüner Strom Label certifies only 100\% renewable products. It is supported by environmental and solar energy organizations and does not certify utility offerings if the company is involved in nuclear power generation. As of July 2001, the Grüner Strom program certified 46 products, ${ }^{48}$ primarily those offered by municipal utilities and Naturstrom AG.

More recently, OK-Power was launched by the Institute for Research on Applied Ecology, the Consumer Organization of Northrhine-Westphalia, and Bremer EnergieKonsens, a citizen's forum on sustainable energy issues. The program allows up to $50 \%$ of the electricity in a green power product to be generated from fossil-fueled cogeneration plants. OK-Power has certified five products to date. ${ }^{49}$

\footnotetext{
${ }^{47}$ https://eon-mixpower.eon-energie.com/, February 13, 2002

${ }_{48}$ http://www.eurosolar.org/vereinnetz/gsl_anbieter.html, October 4, 2001

${ }^{49}$ http://www.okpower.de/okprodfr.html, October 4, 2001
} 
The third program is actually a set of six different standards issued by TÜV, the German association for technical supervision, which certifies and tests a wide range of technical products, including motor vehicles. The program generally has less-stringent environmental standards for green power offerings than the other programs. For example, it certifies pure hydro products without a minimum requirement for additional environmental improvements or new capacity. TÜV has certified 25 products or generators in Germany and another 18 in Austria and Switzerland. ${ }^{50}$

The Federal Environmental Agency, Umweltbundesamt, which manages an environmental labeling program called Blauer Engel (or Blue Angel), decided in early 2000 not to expand the program to include electricity products.

\section{Policies Affecting the Green Power Market}

German renewable energy policy has traditionally emphasized direct support of renewable generation rather than providing incentives on the retail side of the market. Renewable generators in Germany have received guaranteed minimum fixed-price payments for each $\mathrm{kWh}$ supplied to the grid. These payments are then evenly shared among all electricity consumers. In 2000, the German government significantly increased the feed-in tariffs, particularly for PV, which now receives about 48 eurocents $/ \mathrm{kWh}$ ( U.S. $43 \notin / \mathrm{kWh}$ ), while wind generators get about 8 eurocents $/ \mathrm{kWh}(\sim \mathrm{U} . \mathrm{S} .7 \notin / \mathrm{kWh})$. This has given a boost to green generation capacity, but the impact on the retail green power market is unclear. Some marketers view the strong incentives paid to renewable generators as a barrier to green power marketing. They are concerned that consumers will feel that they have already supported renewables with their tax dollars and may not be interested in voluntarily purchasing green power. Certification organizations, in particular OK-Power, have tried to address this issue by setting standards for the inclusion of government-subsidized capacity in green power products.

\section{Outlook}

Green power marketing has had some success in Germany's competitive electricity market, with the overall market penetration rate at about $1 \%$. To date, the green power market has been limited to some extent by retail market barriers and strong supply-side government support for renewable generation. Going forward, there are few signs of a near-term boost for green power marketing in Germany. After the initial success of E.On Aquapower and RWE's early green-pricing programs, the large utilities have returned to less aggressive marketing tactics. It remains to be seen whether the possible involvement of major utilities in planned large offshore wind parks will bring new momentum to the green power market. The more successful new entrants will probably continue to expand their customer base over time.

\footnotetext{
${ }^{50}$ http://www.tuev-nord.de/leistung/umw/oeko/referenz.htm, October 4, 2001, http://www.tuevsued.de/msps/management/ntlsxgryyjxh.html, October 4, 2001
} 


\section{Japan}

\section{Power Market Overview}

In May 1999, the Japanese Diet (parliament) adopted legislation to allow the electricity market to be partially opened to competition. As of March 2000, large industrial and commercial customers, who consume about one-third of the nation's electricity, have been able to choose their electricity suppliers. Residential consumers are served by the country's 10 privately operated utilities. A government committee continues to study restructuring options. In 1999, the primary sources used to generate electricity were fossil fuels $(59 \%)$ and nuclear $(30 \%)$, followed by hydropower $(8 \%)$. Renewable sources such as geothermal, solar, and wind accounted for less than 3\% of total electricity supply. Japan has the highest electricity prices of all OECD countries. ${ }^{51}$

\section{Green Power Marketing Activity}

In the fall of 2000, all 10 of Japan's electric utilities began offering their customers the option to contribute to a green power fund to support the development of wind and solar systems. For example, Tokyo Electric Power Company (TEPCO) offers a program through which customers can contribute an additional 500 Yen or more each month though their electricity bills. TEPCO matches customer donations and administers the program, while a nonprofit organization manages and operates the fund. ${ }^{52}$ The other utility programs are structured in the same way, except Kansai Electric, which set a minimum contribution level of 100 Yen per month. Some utilities have used conventional media, such as running full-page ads in major newspapers, to advertise their green power programs. Collectively, the utilities have nearly 38,000 customers participating in the green pricing programs. ${ }^{53}$ Tokyo Electric has obtained the most customers, with more than 15,000 customers participating as of February 2002.

In Hokkaido, a wind power cooperative collects funds to support the development of new wind projects in the region. Under the program, members can make contributions by adding $5 \%$ to their electricity bills, while non-members can contribute directly to the Hokkaido Green Fund. In addition to its contribution program, the cooperative formed Hokkaido Civic Wind to allow members to purchase shares of future wind projects for 500,000 Yen in return for dividends from the sale of electricity from the wind turbines. ${ }^{54}$

At least one company markets green power to larger commercial and industrial customers. The Japan Natural Energy Company (JNEC), which was formed in late 2000 as a joint venture of TEPCO and 10 other companies, sells wind energy certificates to business customers. The company has signed contracts to supply wind power to more than 25 large Japanese companies, including Sony, Epson, Toyota, and Hitachi. Under the agreements, JNEC will provide certificates representing a total of 36 million $\mathrm{kWh}$ of

\footnotetext{
${ }^{51}$ EIA (2001b).

${ }^{52}$ EnergyInfo Source, Inc. (2000).

${ }^{53}$ Ohbayashi (2001).

${ }^{54}$ Ohbayashi (2001).
} 
wind power at a premium of $4 \mathrm{Yen} / \mathrm{kWh}(\sim \mathrm{U} . \mathrm{S} .3 .4 \varnothing / \mathrm{kWh})$ for 15 years. JNEC also plans to expand its marketing activities and has entered into agreements to purchase the output of three additional wind projects with a combined capacity of about $20 \mathrm{MW} .^{55}$ Table 7 summarizes the green power products offered in Japan.

\begin{tabular}{|l|c|c|c|l|l|}
\hline & $\begin{array}{c}\text { Estimated } \\
\text { Marketers/ } \\
\text { Utilities (\#) }\end{array}$ & $\begin{array}{c}\text { Estimated } \\
\text { Customers } \\
\text { (\#) }\end{array}$ & $\begin{array}{c}\text { Price } \\
\text { Premiums }\end{array}$ & Resources & Examples \\
\hline $\begin{array}{l}\text { Utility } \\
\text { Contribution } \\
\text { Programs }\end{array}$ & 10 & $\sim 38,000$ & $\mathrm{~N} / \mathrm{a}$ & $\begin{array}{l}\text { Wind and } \\
\text { solar }\end{array}$ & $\begin{array}{l}\text { Tokyo Electric, } \\
\text { Kansai Electric }\end{array}$ \\
\hline $\begin{array}{l}\text { Other } \\
\text { Marketers }\end{array}$ & 2 & $\sim 50$ & $\begin{array}{c}4 \mathrm{Yen} / \mathrm{kWh} \\
(\sim \mathrm{U} . \mathrm{S} . \\
3.4 \varnothing / \mathrm{kWh})\end{array}$ & Wind & $\begin{array}{l}\text { Japan Natural } \\
\text { Energy Company, } \\
\text { Hokkaido Civic } \\
\text { Wind }\end{array}$ \\
\hline Total & 12 & $>38,000$ & & & \\
\hline $\begin{array}{l}\text { Includes products offered as of the fall of } 2001 . \\
\text { Source: Information is derived from product information posted on utility and marketer Web sites. }\end{array}$ \\
\hline
\end{tabular}

Table 7: Classification of Green Power Products in Japan

\section{Policies Affecting the Green Power Market}

The Japanese parliament is considering legislation to implement a renewable portfolio standard and an associated green certificate-trading program. In March 2002, the Cabinet adopted a portfolio standard policy, which is now under consideration by the Parliament.

\section{Outlook}

Utilities and marketers have only recently begun to market green power to customers in Japan. Given the short time that these programs have been offered, it is difficult to assess customer response and the market potential. Nevertheless, with more than 38,000 customers subscribing to the utility programs in the first 16 months, there appears to be consumer interest in green power. However, the impact on renewable energy development is likely to be limited based on experience with contribution programs in other countries. Typically, customer donations are not sizeable enough to support the development of significant renewable energy capacity. In terms of future green power sales, the most likely area for significant growth lies with the commercial and industrial sector. The early success of the JNEC indicates an interest on the part of large businesses to purchase green power. However, the debate over the adoption of a renewable portfolio standard creates some uncertainty that may hinder the development of the voluntary green power market.

\footnotetext{
${ }^{55}$ Japan Natural Energy Company $(2001,2000)$.
} 


\section{The Netherlands}

\section{Power Market Overview}

In The Netherlands, large customers ( $>2 \mathrm{MW}$ ) gained access to competitive suppliers in August 1998. Commercial customers were given a choice in January 2002, and residential customers will gain access to alternative suppliers starting in 2004. As of July 1,2001 , all customers have had the ability to switch to a green electricity supplier. The introduction of competition has stimulated mergers and acquisitions in the power sector. In fact, three out of four major generating companies have been acquired by foreign utilities. After several mergers, Essent and Nuon have emerged as the two dominant retail suppliers, serving $37 \%$ and $32 \%$ of the nation's customers, respectively. The third largest supplier, Eneco, has a $17 \%$ market share. ${ }^{56}$ The fuel mix in the Netherlands is dominated by gas (58\%) and coal (29\%), with $28 \%$ of the electricity supplied from cogeneration facilities. ${ }^{57}$ Renewable energy accounts for $5 \%$ of total electricity generation, much of which is municipal solid waste incineration. While the country has good wind resources, growth has been hindered by local opposition and planning problems.

\section{Green Power Marketing Activity}

In the Netherlands, green electricity was first introduced in 1995. All 12 electricity distribution companies have offered green power since 1999. Green power sales grew considerably in late 1999 with the help of a marketing and media campaign launched by WWF, a global environmental organization. The campaign helped to increase the number of green electricity customers from 100,000 in September 1999 to 140,000 in January $2000{ }^{58}$ Since then, demand has been fueled by tax exemptions for green electricity and heavy advertising by utilities hoping to increase customer loyalty on the eve of competition. An estimated 775,000 customers, or about $13 \%$ of residential electricity customers, were purchasing green power as of April 2002. ${ }^{59}$ And, in some regions, the market share is as high as $20 \% .{ }^{60}$ The vast majority of customers are buying green power from their incumbent utilities — only about 50,000 customers had switched to alternative suppliers as of the fall of 2001. ${ }^{61}$ Based on an average household electricity consumption of 3,300 kWh/year, we estimate that as much as 2,500 $\mathrm{GWh}$ of green electricity is being sold annually, which is greater than the annual generation of renewable energy in the Netherlands. In order to meet demand, marketers have been importing green electricity or green certificates from other European countries.

The products offered are typically a blend of wind, hydro, and biomass resources, often including waste incineration. Three of the national marketers-Nuon, Essent, and Eneco-include a small percentage of solar (1-2\%) in their resource mix. Nuon sells a

\footnotetext{
${ }^{56} \mathrm{ECN}(2000)$, p. 37

${ }^{57} \mathrm{ECN}$ (2000), p. 34

${ }^{58}$ Van Vliet/Wüstenhagen/Chappells (2000), p. 4

${ }^{59}$ Heijnes (2002).

${ }^{60}$ Ecofys (2001), p. 15

${ }^{61}$ www.greeenprices.nl/nl/newsitem.asp?nid=231, October 3, 2001
} 
blend of wind, hydro, and solar at a slight premium of 0.45 eurocents/kWh $(\sim$ U.S. $0.4 \notin / \mathrm{kWh}$ ), which is about $8 \%$ more per $\mathrm{kWh} .{ }^{62}$ Essent's green power product is a nopremium blend of domestic biomass, hydro, wind, and solar resources. ${ }^{63}$ However, given the constraints of renewable energy generation in the Netherlands and the rapid growth in customer demand, the company may not be able to make the claim that the power is "Groene Stroom" (made in Holland) in the future. Eneco sells a blend of biomass, hydro, wind, and solar at a price premium of just under $10 \%$. The company also promises to invest in new wind power projects. ${ }^{64}$ Rendo offers a large hydro product supplied from imports. In early 2002, another half dozen green power providers entered the Dutch market.

To date, import activity has included hydro deals between Nuon and ewz of Switzerland and Eneco and Vattenfall of Sweden, as well as a green certificate deal between Nuon and a landfill gas facility in New Jersey. ${ }^{65} \mathrm{New}$ government rules on imported power will make hydro imports financially less attractive (see below) and we may begin to see an increase in the fraction of power supplied from new renewables in the future. ${ }^{66}$ Table 8 provides a rough indication of the types of green power products offered in the Netherlands.

\begin{tabular}{|l|c|c|c|c|c|l|}
\hline Product Categories & $\begin{array}{c}\text { New } \\
\text { Capacity }\end{array}$ & Import & $\begin{array}{c}\text { Price } \\
\text { Premium }\end{array}$ & $\begin{array}{c}\text { Estimated } \\
\text { Customers } \\
\text { (\#) }\end{array}$ & $\begin{array}{c}\text { Estimated } \\
\text { Marketers } \\
\text { (\#) }\end{array}$ & Examples \\
\hline Wind & $>50 \%$ & $0 \%$ & $5-10 \%$ & $\sim 6,000$ & 1 & $\begin{array}{l}\text { Echte } \\
\text { Energie }\end{array}$ \\
\hline $\begin{array}{l}\text { Hydro, } \\
\text { waste/biomass, some } \\
\text { wind }\end{array}$ & $<50 \%$ & $<25 \%$ & $\begin{array}{c}-3 \text { to }+10 \\
\%\end{array}$ & 760,000 & $>15$ & $\begin{array}{l}\text { Nuon, } \\
\text { Eneco, } \\
\text { Essent }\end{array}$ \\
\hline Large hydro & $0 \%$ & $>50 \%$ & $0-5 \%$ & $\sim 10,000$ & 1 & Rendo \\
\hline Total & & & & $\sim 775,000$ & $>15$ & \\
\hline
\end{tabular}

Table 8: Classification of Green Power Products in the Netherlands

\section{Pricing}

In 1999, typical premiums were 1 eurocents/kWh to 2 eurocents/kWh ( U.S. 0.9 to 1.8 $\phi / \mathrm{kWh}) .{ }^{67}$ The combination of increasing energy taxes (REB) and the tax exemption for green electricity that took effect January 1, 2000, has resulted in prices for green electricity, in some cases, below those for conventional electricity. The energy tax increased another $50 \%$ on January 1, 2001, bringing the total amount of the tax to 5.5 eurocents/kWh ( U.S. $5 \notin / \mathrm{kWh})$ for small consumers $(<10,000 \mathrm{kWh} /$ year $)$. The tax

\footnotetext{
${ }^{62}$ On an annual basis (including fixed charges), the premium is about $3.6 \%$.

${ }^{63}$ www.essent.nl/essent/index2.jsp?context_id=0, November 5, 2001

${ }^{64}$ www.ecostroom.nl/ecostroominfo/faq.html, November 5, 2001

${ }^{65}$ www.greenprices.nl/nl/newsitem.asp?nid=197, August 17, 2001

${ }^{66}$ For example, one could imagine Dutch utilities contributing to the development of new wind power in Norway.

${ }^{67}$ Van Vliet, Wüstenhagen, Chappells (2000).
} 
exemptions for green power have driven demand to a point where it now exceeds supply. As a result, some utilities have stopped advertising their green power products or have begun wait-listing customers because they could not supply enough domestically generated green electricity.

Currently, the major green power marketers charge either no premium or a small premium of $1.5-9.5 \%$. Figure 3 shows the price premiums for an average household in Amsterdam for the eight national green power marketers. One marketer, Energieconcurrent, still sells green electricity at a discount.

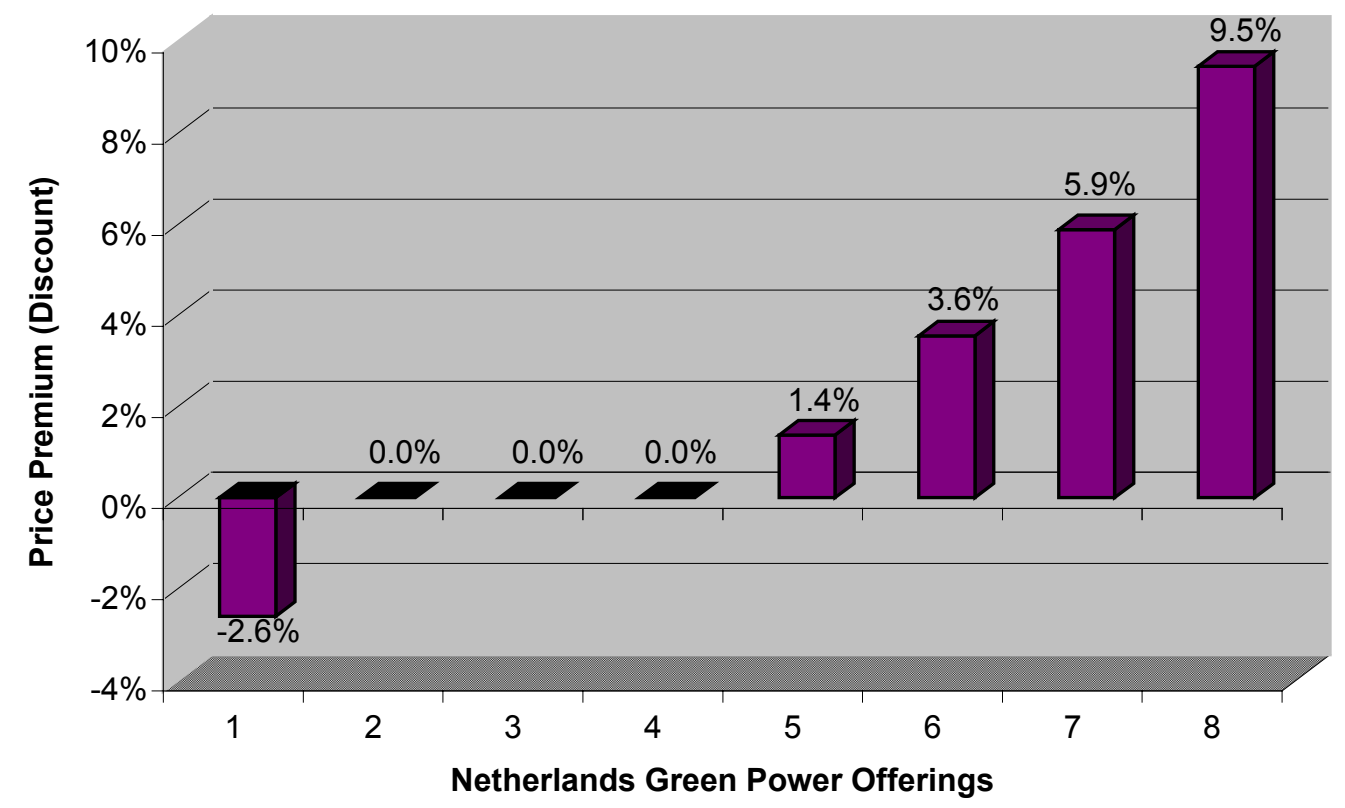

Figure 3: Price Premium for Green Power Products in the Netherlands ${ }^{68}$

\section{Suppliers}

The three major utilities - Essent, Nuon, and Eneco - also are the primary green electricity suppliers, with a combined market share of $85 \%$ based on announced customer figures. All of them have invested heavily in advertising, including television. Nuon also is a strategic investor in U.S.-based Green Mountain Energy Company and in unit [e]nergy of Germany. All other distribution utilities are selling green power products as well. There also are a few new entrants. Energie Concurrent is a marketer that sells an $80 \%$ wind and $20 \%$ biomass product at a price $2-3 \%$ below standard rates. Echte Energie sells $100 \%$ wind energy and solar panels. The company started as an online supplier in

\footnotetext{
${ }^{68}$ Authors' own calculations based on data available at www.greenprices.nl. Assumptions: Annual consumption of 4,000 kWh/year, prices for NL-1090 Amsterdam, household with single meter, prices valid as of October 1, 2001. In absolute terms, the annual cost for 4,000 kWh of conventional power in this area is 698.02 Euros, while the cost of the green power products ranges from 679.86 Euros to 764.16 Euros.
} 
May 2001 and recently extended its distribution channels to 100 wholefood stores across the Netherlands. ${ }^{69}$ There is also a wind energy cooperative, SGEP, through which members become co-owners of the group's wind turbines. The energy is fed into the local electricity grid and the group has a net metering arrangement with the local utility. ${ }^{70}$

\section{Certification}

No certification programs have been widely adopted in the marketplace. The environmental organization, WWF, does some monitoring and verification of green power products, but it has not developed a formal program, because stakeholders could not reach consensus on certification criteria. Zeeuwse Milieufederatie, a regional environmental organization, launched a green electricity-labeling program, but few marketers have applied for certification under the program. With strong demand for green power and increasing reliance on foreign-sources of green power, there may be a growing need for a national green power certification program in the Netherlands ${ }^{71,72}$ On the other hand, the government recently implemented a green certificate trading system, which could serve as the mechanism for verifying green energy transactions, alleviating the need for independent auditing and verification.

\section{Public Policy Support for the Green Power Market}

The striking success of the green power market in the Netherlands has been facilitated by a variety of public policy support measures. The most important policy driver is arguably the tax exemption for green power purchases. The ecotax, which was introduced in 1997, has increased substantially each year since then, particularly for small consumers using less than 10,000 kWh/year. Since 1998, green power customers have been exempt from paying the tax. As a result, green power has steadily become more cost-competitive with conventional power to the point where green power is now cheaper, or-as it is marketed today - is offered at about the same price, but at healthy profit margins for the marketers. The challenge going forward will be for suppliers to develop new projects to keep up with demand.

Government purchasing has also played a role in supporting the market for green power. Today, four federal ministries - including the Ministries of the Environment, Economic Affairs, Education, and Foreign Affairs - purchase green power to meet all of their electricity needs. In addition, the government plans to purchase green power to meet $50 \%$ of the public sector's electricity needs during $2002-2004$, as part of a national strategy to achieve carbon neutrality. ${ }^{73}$

Another important regulatory element is the Dutch system of tradable green certificates. Introduced in 1998, the system is part of a voluntary agreement between the electric

\footnotetext{
${ }^{69}$ Financial Times (2001c).

${ }^{70}$ Van Vliet, Wüstenhagen, Chappells (2000)

${ }^{71}$ www.greenprices.nl/nl/newsitem.asp?nid=135, March 15, 2001

${ }^{72}$ www.greenprices.nl/nl/newsitem.asp?nid=181, July 3, 2001

${ }^{73}$ Financial Times (2001c).
} 
power industry and the Ministry of Economic Affairs. ${ }^{74}$ Under the original agreement, the utilities committed to supply $1,700 \mathrm{GWh}$ of renewable electricity by the end of 2000 . A new certificate-trading system managed by the Dutch grid operator, TenneT, has replaced the original system. ${ }^{75}$ According to new government rules, imports of foreign green certificates were accepted starting January 1, 2002. Imported green certificates are eligible for tax exemptions in the Netherlands, but there are certain restrictions designed to avoid double selling and to limit windfall profits for foreign generators. Hydropower is not eligible for the tax exemption, but is being sold to large customers who do not have to pay the REB tax. ${ }^{76}$ Furthermore, certificates will only be accepted from countries with competitive electricity markets (currently only Germany, Sweden, Norway, Finland, and the United Kingdom) and there must be sufficient import capacity for physical delivery of the imported electricity. There are also limitations for trading green electricity in other countries that will impact the ability of Dutch companies to import supplies. ${ }^{77}$

A renewable portfolio standard was suggested in the National Environmental Plan (NMP4), which would have obliged all residential customers to obtain at least 3\% of their electricity from renewable sources. However, in light of the success of the voluntary green power market and the shortages of domestic green power supplies, the government has decided not to introduce a purchase requirement. ${ }^{78}$

\section{Outlook}

The market for green electricity in The Netherlands has been very successful relative to other countries. And with steady increases in the number of green customers and the entrance of several new green marketers, it shows signs of continued growth. The challenge going forward is how to meet additional green power demand, given that essentially all existing domestic renewable energy generation has been sold. Up to this point, green power marketing has not resulted in the development of much new renewable capacity. Given the planning constraints in the Netherlands, where there is very high population density, there are two main options: building offshore wind projects or increasing imports. The debate on the issue of offshore projects is in a relatively early stage in the Netherlands. ${ }^{79}$ As for imports, the new rules set by the government regarding issuing green certificates for qualified imports of green electricity could lead to a system where Dutch green power customers support the development of new renewable energy projects in other countries. $^{80}$

\footnotetext{
${ }^{74}$ Haas, et al. (2001), pp. 20 ff., ECN (2000), p. 27

${ }^{75}$ Financial Times (2001b) or http://www.groencertificatenbank.nl

76 "Rules for the assignment of green certificates to import renewable electricity are clarified," http://www.greenprices.nl/nl/newsitem.asp?nid=212, September 18, 2001"

${ }_{77}^{77}$ Ww.greenprices.nl/nl/newsitem.asp?nid=212, September 18, 2001

${ }^{78}$ www.greenprices.nl/nl/newsitem.asp?nid=227, October 3, 2001; www.greenprices.nl/nl/newsitem.asp?nid=165, June 13, 2001

${ }^{79}$ Coleman (2001).

${ }^{80}$ However, the majority of renewable capacity in The Netherlands' largest neighboring country, Germany, is subsidized by the German government scheme, so it will not qualify for Dutch green electricity certificates. France and other countries are likely to follow the German system.
} 


\section{Sweden}

\section{Power Industry Overview}

The Swedish power market opened to retail competition in January 1996. Initially, only large customers participated in the open market because customers were required to install hourly meters to switch suppliers, which proved costly for small customers. In late 1999 , the hourly meter requirement was lifted; and today, about $15 \%$ of residential customers have switched to an alternate supplier. In 2000, the primary fuel sources used to generate electricity were hydro (55\%) and nuclear (38\%), followed by fossil fuels and biofuels $(6 \%) .{ }^{81}$

\section{Green Power Marketing Activity}

Retail energy suppliers have offered green power since early 1996, when the market opened to retail competition. Today, more than 50 companies offer green power options to electricity customers across Sweden, and all consumers have access to green power. While most providers generate their own power, about a third of the companies purchase green power from generators and resell it to customers. Many of the green power products are offered by municipal or public utilities. Table 9 summarizes green power offerings.

\begin{tabular}{|l|l|l|l|}
\hline \multicolumn{1}{|c|}{ Resources } & $\begin{array}{l}\text { Estimated } \\
\text { Number of } \\
\text { Marketers }\end{array}$ & \multicolumn{1}{|c|}{ Price Premiums } & \multicolumn{1}{|c|}{ Examples } \\
\hline $\begin{array}{l}\text { 100\% hydro from } \\
\text { existing, large- } \\
\text { scale projects }\end{array}$ & $>25$ & $\begin{array}{l}\text { 0 to 4.8 öre/kWh } \\
\text { (U.S. 0.0 to 0.48 } \\
\text { ф/kWh) }\end{array}$ & $\begin{array}{l}\text { Birka Energi, Sydkraft Försäljning, } \\
\text { Vattenfall Energimarknad, Jämtkraft }\end{array}$ \\
\hline $\begin{array}{l}\text { Wind, hydro, } \\
\text { biomass }\end{array}$ & $>15$ & Not available & Graninge, Vattenfall Energimarknad \\
\hline $\begin{array}{l}100 \% \text { wind or } \\
\text { other renewable } \\
\text { sources }\end{array}$ & $>10$ & $\begin{array}{l}\text { 2 to 6 öre/kWh } \\
\text { (U.S. 0.2 to 0.6 } \\
\text { ф/kWh) }\end{array}$ & $\begin{array}{l}\text { Birka Energi, Sydkraft Försäljning, } \\
\text { Vattenfall Energimarknad }\end{array}$ \\
\hline $\begin{array}{l}\text { Sources: Swedish Society for Nature Conservation http://www.snf.se/bmv/english/index.htm, Goteborg, } \\
\text { Sweden; Greenprices.com http://www.greenprices.com/se, accessed 10/29/01. }\end{array}$
\end{tabular}

\section{Table 9: Classification of Green Power Products in Sweden}

According to the Swedish Society for the Conservation of Nature (the leading certifier of green power suppliers), green power sales increased $32 \%$ during 2000 to $9.0 \mathrm{TWh}$ (see Table 10). ${ }^{82}$ This figure represents about $6 \%$ of total electricity sales in Sweden. Nonresidential customers, particularly commercial and industrial customers and public agencies, represent a significant portion of green power sales to date. No data are available on the number of customers purchasing green power.

\footnotetext{
${ }^{81}$ Swedish National Energy Administration (2001).

${ }^{82}$ Financial Times (2001a); Swedish Society for Nature Conservation (2001).
} 
The green power products are generally $100 \%$ renewable energy offerings supplied from either a mix of several renewables, or a single resource, such as hydro or wind. Many companies offer products supplied from existing hydropower projects, with a small portion of the power from new biomass or wind projects. In terms of pricing, a small number of products have been sold at the cost of conventional electricity, while others have held premiums as high as $10-30 \%$. Of the dozen or so products examined, price premiums ranged from 0.5 öre/kWh to 6 öre/kWh (U.S. 0.05 to $0.6 \phi / \mathrm{kWh}){ }^{83}$ The average price premium in 2000 was approximately 1.4 öre/kWh, ( U.S. $0.14 \notin / \mathrm{kWh})$, which translates to about an $8-10 \%$ premium over the cost of the electricity (generation portion only) for commercial and industrial customers. ${ }^{84}$

\begin{tabular}{|c|c|c|c|}
\hline Year & $\begin{array}{c}\text { Certified Green Power } \\
\text { Sales (TWh) }\end{array}$ & Increase (\%) & Share of Total (\%) \\
\hline $1996^{1}$ & 4.0 & $\mathrm{~N} / \mathrm{a}$ & $2.8 \%$ \\
\hline $1997^{1}$ & 4.7 & $18 \%$ & $3.2 \%$ \\
\hline $1998^{2}$ & 6.4 & $36 \%$ & $4.4 \%$ \\
\hline $1999^{2}$ & 6.8 & $6 \%$ & $4.7 \%$ \\
\hline $2000^{2}$ & 9.0 & $32 \%$ & $6.1 \%$ \\
\hline
\end{tabular}

Table 10: Growth Trend in Green Power Sales in Sweden

\section{Suppliers}

Some suppliers have multiple product offerings to appeal to a variety of customers. For instance, Vattenfall offers a total of four products: two $100 \%$ hydro products certified by different organizations, a $100 \%$ wind product, and a blend of wind and hydro. Two of the products are offered to large customers and only on a contract basis. Vattenfall has also offered wholesale green power. For example, Vattenfall supplies Tranas Energy, a municipal utility in southern Sweden, with hydropower from its projects on the Lule River. Tranas, in turn, sells the power to its commercial and industrial customers at no extra cost to retain them in the competitive market. ${ }^{85}$

Although most companies are offering conventional green power service, several companies offer programs through which customers invest in shares of a wind power project, and the green power premium is determined in part by the financial return on the project. For example, in 1998 Falkenberg Energi began offering consumers the option of making an initial investment of 4,000 Swedish Krona (SKR) ( U.S.\$500) to purchase $1,000 \mathrm{kWh}$ of wind power each year at 22.5 öre $/ \mathrm{kWh}$ ( $\sim$ U.S. $2 \notin / \mathrm{kWh})$, compared to about $40 \mathrm{orre} / \mathrm{kWh}(\sim \mathrm{U} . \mathrm{S} .4 \notin / \mathrm{kWh})$, the market price of electricity as of late 1999 . The investment in the wind project pays a return to the consumer based on the market price

${ }^{83}$ Greenprices.com (2001).

${ }^{84}$ Financial Times (2000a).

${ }^{85}$ Financial Times (2000b). 
for electricity —in 1999 the return was 6.4\%. As of late 2001, Falkenberg Energi had sold out the shares from its own wind farm, and had begun selling shares from another wind farm run by Sveriges Vindkraftkooperativ (Swedish Wind Power Cooperative).

Although business customers have shown a strong interest in green power, the lack of interest among residential consumers can be explained in part by insufficient marketing and perhaps, consumer apathy. Few electricity providers have aggressively marketed green power products, and none of the large suppliers have done so. In fact, some large suppliers have criticized green power, pointing out that electricity is blended once in the transmission lines and that green power is more expensive. In addition, consumers are to some extent overwhelmed by new choices in telecommunications, finance, and other areas in addition to electricity. ${ }^{86}$

\section{Certification}

There are three distinct certification programs for green power products in Sweden. The most widely used is the "Bra Miljöval" (or good environmental choice) eco-labeling program offered by the Swedish Society for Nature Conservation since 1996. Since its inception, the Bra Miljöval program has certified 21.8 TWh of green power sales. Currently, it certifies more than 50 green power providers. Renewable resources eligible for certification include wind, solar, biofuels, and hydro resources. Recently, the Society for Nature Conservation tightened its certification criteria and now requires hydropower projects to be built before 1996, meet minimum flow standards, and contribute to an impact mitigation fund. The Bra Miljöval program also requires products generated primarily from hydropower to have at least $5 \%$ of the power content supplied from biomass, wind, or solar resources, which is essentially equivalent to a new renewables requirement. ${ }^{87}$

Under the other certification programs, the Certified Environmental Product Declaration (EPD) and Production Specified Electricity (PS), the consumer determines whether the electricity is generated in an environmentally friendly manner. The EPD program, which was developed by the Swedish Environmental Management Council as an initiative of the trade and industry sector, uses lifecycle analysis to determine the environmental effects of the generation sources. There are no minimum environmental standards or other restrictions placed on the use of the logo. Certification can be obtained from a qualified certifier such as the Svenska Provning och Forskningsinstitut (SP) or the SIS SAQ. Currently, Vattenfall Energimarknad and Sydkraft Försäljning AB offer EPD-certified products. In the case of the PS program, the supplier itself guarantees that the electricity supplying the product is from the renewable resources identified in marketing claims. ${ }^{88}$

\footnotetext{
${ }^{86}$ Hopkins (2001).

${ }^{87}$ Swedish Society for Nature Conservation (2001); Holt (2001).

${ }^{88}$ Greenprices.com (2001).
} 


\section{Policies Affecting the Green Power Market}

There are a variety of support programs in place for renewable energy projects in Sweden. Renewables with an output of less than 1.5MW currently receive a subsidy of 9 öre/kWh ( U.S. $0.9 \phi / \mathrm{kWh})$, funded partially through a charge added to transmission services. There are also grants available for up to $15 \%$ of the investment costs of smallscale hydro projects and up to $25 \%$ of the investment costs of biomass-fired combined heat and power (CHP) projects. Wind projects are eligible for an investment and operating grant of 18.1 öre $/ \mathrm{kWh}(\sim \mathrm{U} . \mathrm{S} .1 .8 \notin / \mathrm{kWh})$, which is equivalent to the electricity tax in southern Sweden. The government plans to replace the subsidies and introduce a green certificate program in 2003 to support new renewable generation. The details of the system are being developed. Under the proposed certificate-trading program, electricity users will be required to purchase a certain percentage of their power from renewable sources. ${ }^{89}$

Sweden also has taxes on both the consumption and production of electricity. Recently, the government instituted a "green tax exchange," which raised taxes on environmentally harmful activities. For most consumers, the tax imposed on electricity consumption is equivalent to 18.1 öre $/ \mathrm{kWh}(\sim \mathrm{U} . \mathrm{S} .1 .8 \notin / \mathrm{kWh})$, but the amount varies regionally and among customer classes. Certain industries, such as manufacturing, agriculture, mining, and forestry, are exempt from electricity taxes. The government is currently conducting a review of the energy tax system to make it more transparent and to take into account environmental impacts. ${ }^{90}$

\section{Outlook}

There has been significant activity in the Swedish green power market to date, particularly with respect to large nonresidential consumers. Green power sales are equivalent to about $6 \%$ of Sweden's total electricity market. There are a large number of suppliers offering products - and continued growth appears likely. However, there has been little interest among residential customers thus far. Further, very little new renewable capacity has been installed to meet demand. Many of the products offered to date are supplied with power from existing hydro projects installed before 1996, with only a small portion $(5 \%)$ of power supplied from new renewables. Some additional environmental improvements may result from the requirement that certified hydro facilities contribute to a fund for environmental improvements on impacted rivers. However, many of these products offer minimal support for new renewables development. Looking toward the near future, the movement toward replacing existing renewables subsidies with a green certificate trading system creates some uncertainty for the green power market. Under the current proposal, users would be required to purchase a certain portion of their electricity from renewables starting in 2003. The mandatory purchase requirements could stifle consumer interest in voluntary purchases. However, the details of this program have not yet been developed and the impacts on the green power market remain to be seen.

\footnotetext{
${ }^{89}$ Swedish National Energy Administration (2001); Financial Times (2000b).

${ }^{90}$ Swedish National Energy Administration (2001).
} 


\section{Switzerland}

\section{Power Market Overview}

Switzerland is not a member of the European Union and, thus, it does not have to comply with European legislation regarding energy market restructuring. However, last year legislation was drafted to implement restructuring, and a public referendum will be held in September 2002 to determine whether it will proceed. If the referendum is approved, then the Swiss market will be opened for large industrial and all green electricity customers in 2002, while retail choice for commercial and residential customers would follow three to six years later. Despite the lack of formal competition to date, many large industrial customers have already negotiated lower prices or even switched to alternative suppliers in recent years. In addition, several utilities have launched new products or rebranded their companies in anticipation of a competitive market. Switzerland's fuel mix is dominated by hydro (56\%) and nuclear (40\%), with the remainder supplied from fossil fuels and renewables, such as wind, biomass, and solar. Because of its central location in Europe and its extensive hydro peaking capacity, Switzerland has been heavily involved in international electricity trading. Imports and exports account for about one-third of domestic power generation.

\section{Green Power Marketing Activity}

Today, more than 100 electric utilities offer green power. The first programs emerged in the mid-1990s when a number of utilities began offering solar power options. ${ }^{91}$ Currently, there are about 30,000 households $(1.5 \%)$ and a small number of businesses that participate in these programs. They have resulted in the installation of about $5 \mathrm{MW}_{\mathrm{p}}$ of photovoltaics. ${ }^{92}$ The relatively strong demand for these offerings is remarkable given the fact that they are typically priced at premiums on the order of $300 \%$ to $500 \%$ above standard rates. However, customers can choose the number of kilowatt-hours of solar power that they purchase and adjust the monthly cost. ${ }^{93}$

More recently, as the possibility of retail competition grows, a second generation of green power products have appeared. ${ }^{94}$ These rely mainly on hydropower, but provide added environmental value by meeting the criteria of the Swiss green electricity labelling program Naturemade, which requires environmental improvements, minimum flows, and a minimum percentage of power from new renewables (solar, wind, wood, agricultural biogas). Some utilities now also offer two certified products - a low-impact hydro and a new renewables product. About 4,800 customers have signed up for the new low-impact hydro products to date. Table 11 summarizes the various types of green power products offered in Switzerland.

\footnotetext{
${ }^{91}$ Wüstenhagen (1998)

${ }^{92}$ www.oekostrominfo.ch, accessed 4/15/02.

${ }^{93}$ On average, Swiss solar power customers buy $150-200 \mathrm{kWh} / \mathrm{month}$, which is about $5 \%$ of average household electricity consumption.

${ }^{94}$ Wüstenhagen et al. (2002)
} 


\begin{tabular}{|c|c|c|c|c|c|c|}
\hline $\begin{array}{l}\text { Product } \\
\text { Description }\end{array}$ & $\begin{array}{c}\text { New } \\
\text { Capacity }\end{array}$ & Certification & $\begin{array}{c}\text { Price } \\
\text { Premium }^{95}\end{array}$ & $\begin{array}{c}\text { Estimated } \\
\text { Customers } \\
\text { (\#) }\end{array}$ & $\begin{array}{l}\text { Estimated } \\
\text { Products } \\
\text { (\#) }\end{array}$ & Examples \\
\hline Pure Solar & $>50 \%$ & $\begin{array}{l}\text { Naturemade } \\
\text { Star }\end{array}$ & $\begin{array}{c}300-500 \\
\%\end{array}$ & 30,000 & $>100$ & $\begin{array}{l}\text { swisspower } \\
\text { Premium Solar, } \\
\text { IWB Basler } \\
\text { Solarstrom }\end{array}$ \\
\hline $\begin{array}{l}\text { Blends of } \\
\text { hydro, solar, } \\
\text { wind, biogas }\end{array}$ & $>50 \%$ & $\begin{array}{l}\text { Naturemade } \\
\text { Star, TÜV }\end{array}$ & $50-100 \%$ & 5,000 & 5 & axpo Prisma Sky \\
\hline $\begin{array}{l}\text { Low-impact } \\
\text { Hydro }\end{array}$ & $2.5 \%$ & $\begin{array}{l}\text { Naturemade } \\
\text { Star }\end{array}$ & $25-45 \%$ & 6,000 & 3 & $\begin{array}{l}\text { swisspower } \\
\text { Premium Water, } \\
\text { Pure Power } \\
\text { Graubünden, } \\
\text { 1tolenergy water } \\
\text { star }\end{array}$ \\
\hline $\begin{array}{l}\text { Existing } \\
\text { Hydro }\end{array}$ & $0 \%$ & $\begin{array}{l}\text { Naturemade } \\
\text { Basic, TÜV }\end{array}$ & $5-10 \%$ & 4,800 & 2 & $\begin{array}{l}\text { axpo Prisma Blue, } \\
\text { SN Aquapower }\end{array}$ \\
\hline Total & & & & $\sim 46,000$ & $>110$ & \\
\hline
\end{tabular}

Table 11: Classification of Green Power Products in Switzerland

\section{$\underline{\text { Suppliers }}$}

Although there are more than 100 utilities offering green power products, there are currently four major companies that are positioning themselves to supply green power nationally. As is the case of the Netherlands, most of these companies are interested primarily in increasing customer loyalty as they face the prospect of competition.

Ewz, the municipal utility of Zurich, is one of the largest retail supply companies and is also a major producer of hydropower. The company launched its solar product, Solarstrombörse, in 1996 and was an important supporter of the certification program, Naturemade. In 1998, the company founded Swisspower (formerly Swiss Citypower), a marketing and product development company, with 13 other municipal utilities. ${ }^{96}$ Swisspower developed two new products, a premium solar product similar to Solarstrombörse and a low-impact hydro product, both of which are Naturemade certified. Both products are available to Ewz's Zurich-based customers and will be made available to the customers of the participating municipal utilities. They are sold at substantial premiums. With respect to the energy portion of the bill, Premium Solar costs $350 \%$ more per $\mathrm{kWh}$, and Premium Water costs about 45\% more than conventional electricity.

\footnotetext{
${ }^{95}$ On a per-kWh basis, referring to the energy component only, not including fixed charges. Note that customers are usually free to buy only part of their consumption from green power.

${ }^{96}$ For more information, see www.swisspower.ch
} 
Rätia Energie, a hydropower producer in South Eastern Switzerland, ${ }^{97}$ developed a unique green power brand called, Pure Power St. Moritz, in conjunction with the tourism organization of St. Moritz, a well-known mountain resort. It is a low-impact hydropower product offered at a premium. The company also intends to offer the brand to franchising partners abroad. Rätia Energie has a limited customer base, serving a rural area of only 50,000 households. Thus, further success will depend on the creation of a competitive market in Switzerland or exports to Germany and Italy.

1-to-1 energy is a joint venture of BKW FMB Energie AG and some of its distribution partners, located in and around Berne, the capital. ${ }^{98} \mathrm{BKW}$ has been a pioneer in wind energy and in 1996 developed Switzerland's first wind park, which was recently expanded to $4 \mathrm{MW}$ to meet the demand from corporate customers. ${ }^{99}$ The company recently launched two residential retail products (Water Star and Wind Star), which have been certified as Naturemade star. Water Star is a 100\% low-impact hydro product offered at about a $25 \%$ premium, or about 3 eurocents $/ \mathrm{kWh}(\sim \mathrm{U} . \mathrm{S} .2 .7 \phi / \mathrm{kWh})$. Wind Star is supplied from the Juvent wind park and sold at a 100\% premium, or about 12 eurocents/kWh ( $\sim$ U.S. $11 \varnothing / \mathrm{kWh})$. With both products, consumers are free to choose the amount that they want to purchase. The company also has a customized green power offering for commercial customers.

Axpo is the trading and retail subsidiary of NOK, a major nuclear and hydropower generator in northeastern Switzerland. ${ }^{100}$ The company offers three different green power products - Prisma blue, Prisma azur, and Prisma Sky —all of which are TÜV certified. Prisma blue is supplied from existing hydropower sold and sold at a $10 \%$ premium, while the other two products blend solar and biomass with $80 \%$ to $90 \%$ existing hydropower.

\section{Certification}

The Association for Environmentally Sound Electricity (VUE), a newly-formed independent organization supported by environmental organizations (WWF), consumer groups, renewable energy associations, and the electric power industry, launched the Naturemade labeling program in June 2000 following a broad stakeholder process. VUE has developed two separate certification standards - Naturemade Star and Basic - to address hydropower issues. Only products supplied with low-impact hydropower can obtain Star certification, while all hydropower products are eligible for Basic certification. The criteria and assessment procedure for low-impact hydro were developed by EAWAG, the Swiss Federal Institute for Environmental Science and Technology. Both standards require marketers to supply at least $2.5 \%$ of their power from new renewable energy sources (solar, wind, or biomass, built after 1995). ${ }^{101}$

The German TÜV, drawing on its domestic experience with green power certification, also certifies generators and products in Switzerland. Some suppliers have opted for TÜV

\footnotetext{
${ }^{97}$ For more information, see $\underline{w w w . r e p o w e r . c h}$

${ }^{98}$ For more information, see http://www.1to1energy.ch

${ }^{99} \mathrm{http}: / / \mathrm{www} . j u v e n t . c h /$ news.htm, November 15, 2001

${ }^{100}$ For more information, see http://www.axpo.ch

${ }^{101}$ http://www.oekostrom.eawag.ch or Bratrich, Truffer (2001)
} 
certification over Naturemade because it does not require environmental upgrades of hydropower plants or investment in new renewable capacity. However, TÜV is in the process of revising its criteria.

\section{Policies Affecting the Green Power Market}

Traditionally, there has been limited public policy support for renewables in Switzerland, in part because of its low- $\mathrm{CO}_{2}$ fuel mix. After a referendum in 1990 led to a 10-year moratorium on construction of new nuclear power plants, several policy measures were instituted to support the development of alternative technologies. Under the Energie 2000 plan, a number of incentives were created for renewables, including production payments and a number of soft support measures, such as education campaigns, marketing support for utility solar power programs, and seed funding for the Naturemade certification and labeling program.

Another referendum in September 2000 would have increased support for renewables by means of an ecotax with increased fixed-priced payments for renewables but was rejected by a slight majority of voters. Consequently, the Federal Energy Agency's follow-up program for Energie 2000, EnergieSchweiz, has less funding than its predecessor, and mainly focuses on awareness campaigns. ${ }^{102}$ The proposed new energy market regulation, which is subject to the upcoming referendum in September 2002, includes additional support for renewable energy such as a disclosure standard for electricity products and a ten-year transmission charge exemption for small renewable energy generators. ${ }^{103}$

\section{Outlook}

Today, the Swiss market is relatively active, with more than 100 green power products available. Consumer response has been on par with most countries, with about $1-2 \%$ of customers purchasing green power. Many of the green power products offered to date have featured solar or relied heavily on existing hydro resources, and thus, only a small amount of new renewable capacity has been developed to serve green power customers. In the coming years, the Swiss green power market is likely to experience continued growth, given the marketing activities of several larger players, an above average consumer willingness-to-pay for renewables, and the availability of certified low-impact hydropower. Growth could also accelerate if retail customers gain the ability to choose green power providers in 2002.

\footnotetext{
${ }^{102}$ Neue Zürcher Zeitung, 4. October 2001

${ }^{103}$ Econcept/EAWAG (2001).
} 


\section{United Kingdom}

\section{Power Market Overview}

In 1989, the U.K. electricity industry was privatized and large industrial customers gained access to competitive suppliers. The market was opened to commercial customers in 1994, and to residential customers in 1998/1999. The early restructuring of the industry has led to a significant number of mergers and acquisitions. In fact, all of the former regional electricity companies changed owners at least once. In addition, marketers from other industries, particularly British Gas, have entered the market and have begun cross-selling electricity and gas. Overall, the substantial amount of market activity has fueled customer switching. In the beginning of 2001, 6 million customers had chosen an alternative supplier. ${ }^{104}$

The fuel mix in the United Kingdom has traditionally been dominated by coal (77\% in $1990)$ and nuclear (21\% in 1990). More recently the mix has shifted toward gas, which increased from almost $0 \%$ to $26 \%$ throughout the 1990 s, while coal decreased to $44 \%$. Renewable electricity generation, mainly large hydro and biomass, increased modestly from $2.4 \%$ in 1990 to $2.8 \%$ in 1998 .

\section{Green Power Marketing Activity}

Fourteen green power marketers offer products to customers in the United Kingdom today (see Table 12). The total number of customers has recently been estimated to be $45,000 .{ }^{105}$ Most green power offerings originated in the early days of competition in $1989^{106}$ and have not been aggressively marketed since. Both contribution and supply products have been offered. For example, TXU Energi (formerly Eastern Electricity) and London Electricity have offered contribution programs, while RSPB Energy, a program launched by the Royal Society for the Protection of Birds in conjunction with Scottish and Southern Energy is an example of a energy-based product. RSPB, which claims to serve about 7,000 customers, offers green power supplied primarily from new landfill gas, wind, and hydropower resources at no price premium.

A number of competitive green power marketers are also active in the United Kingdom. Ecotricity serves industrial and commercial customers only, whereas unit [e]nergy and Green Energy (U.K.) also serve residential customers. Because of high market-entry costs and unfavorable conditions for intermittent renewables, none of these marketers has had significant success obtaining residential customers thus far. Ecotricity focuses on wind energy and distributed generation, whereas unit[e] sells a mix of wind and hydro. Green Energy (U.K.) claims to offer "renewable energy from wholly British sources,", 107 without specifying the fuel mix. In August 2001, a new marketer, Npower, began

\footnotetext{
${ }^{104}$ http://www.greenprices.nl/uk/newsitem.asp?nid=102, January 22, 2001.

${ }^{105} \mathrm{http} / / / \mathrm{www}$.greenprices.co.uk/uk/newsitem.asp?nid=253, November 1, 2001. This compares to a total of roughly 25 million electricity customers in the United Kingdom.

${ }^{106}$ Lovell (1998).

${ }^{107}$ http://www.greenenergy.uk.com/MainFrameset.asp?page=ProductsPrices.html, Feb. 14, 2002
} 
aggressively marketing a zero-premium green power product in cooperation with the environmental organization Greenpeace. The company, which is a retail subsidiary of the large electric generating company Innogy (formerly National Power), offers a product called "Juice," which will be supplied from a new offshore wind farm near North Hoyle scheduled for completion in 2003. Until the project is complete, the company will supply its customers with power from existing wind and hydro power plants. ${ }^{108}$ Npower has announced a goal of signing up 50,000 customers, which would double the country's green power customers if achieved.

\begin{tabular}{|l|l|l|c|c|c|l|}
\hline Category $^{1}$ & Resources & Certification & $\begin{array}{c}\text { Price } \\
\text { Premium }\end{array}$ & $\begin{array}{l}\text { Estimated } \\
\text { Customers } \\
\text { (\#) }\end{array}$ & $\begin{array}{c}\text { Estimated } \\
\text { Products } \\
\text { (\#) }\end{array}$ & \begin{tabular}{l} 
Examples \\
\hline Energy
\end{tabular} \\
$\begin{array}{l}\text { Wind, hydro, } \\
\text { sometimes } \\
\text { solar, } \\
\text { biomass, } \\
\text { landfill gas }\end{array}$ & $\begin{array}{l}\text { Future } \\
\text { Energy }\end{array}$ & $0-15 \%$ & $\sim 35,000$ & $\sim 6$ & $\begin{array}{l}\text { RSPB Energy, } \\
\text { PowerGen, } \\
\text { npower }\end{array}$ \\
\hline Contribution & $\begin{array}{l}\text { Wind, solar, } \\
\text { small-scale } \\
\text { hydro, } \\
\text { biomass }\end{array}$ & $\begin{array}{l}\text { Future } \\
\text { Energy }\end{array}$ & N/a & $\sim 10,000$ & $\sim 4$ & $\begin{array}{l}\text { TXU Energi, } \\
\text { London } \\
\text { Electricity, } \\
\text { Scottish } \\
\text { Power }\end{array}$ \\
\hline Total & & & & & \\
\hline${ }^{1}$ Some products are actually hybrids of the two categories. & & & & \\
\hline
\end{tabular}

Table 12: Classification of U.K. Green Power Products

\section{Pricing}

Price premiums are difficult to determine because of the differences between the types of products offered (energy and contribution) and the large number of regional tariffs for both conventional and green power. However, we estimate premiums for an average residential customer consuming $4,000 \mathrm{kWh} /$ year to vary roughly between $0 \%$ and $15 \%$ of the total electricity cost, with the majority of offerings in the $2-10 \%$ range. As noted above, both Npower and RSPB Energy charge no price premium (see Figure 4). ${ }^{109}$

\footnotetext{
${ }^{108}$ http://www.greenprices.nl/uk/newsitem.asp?nid=201, August 17, 2001. For more information, see http://www.npower.com/html/juiceandwindpower_4467.htm.

${ }^{109}$ In the commercial customer segment, Ecotricity also follows a no-premium approach.
} 


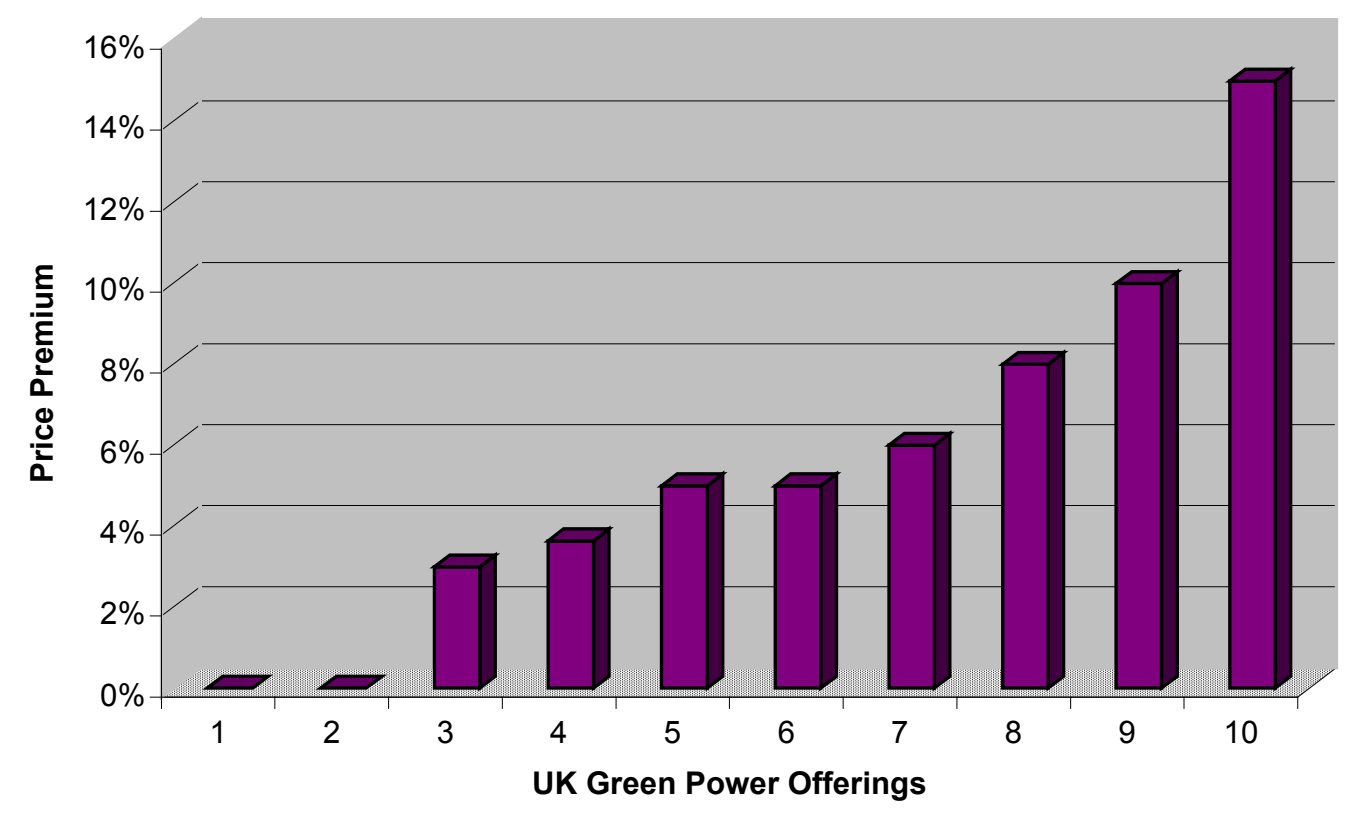

Figure 4: Price Premium for Green Power Products in the United Kingdom ${ }^{110}$

\section{Certification}

The Energy Saving Trust (EST), an independent non-profit company established by the government to help meet the country's Kyoto target, launched an accreditation program called Future Energy in 1999. ${ }^{111}$ The program verifies energy sources and marketer claims and sets standards for renewable energy content - "energy" offerings must be $100 \%$ renewable, while "contribution" programs must invest all funds in new renewable resource development. Any products containing electricity generated from sources considered renewable in government definitions, including solar, wind, large and small hydro, biomass, and landfill gas, are eligible for accreditation, although large hydro is limited to $50 \%$ of the product fuel mix. Currently, the program accredits nine green power products. ${ }^{112}$ In light of the new renewables obligation and the "Guidelines on Green Supply Offerings" recently published by the regulator, Ofgem (Office of Gas and Electricity Markets), Future Energy will be modified and re-launched in June 2002. In the meantime, some marketers have chosen to rely on their own environmental reputations (eg. Ecotricity) or team with an environmental organization such as Greenpeace or WWF (eg. npower, Powergen, Yorkshire electricity) instead of seeking certification.

\footnotetext{
${ }^{110}$ Authors' own calculations based on data available at www.greenprices.nl and on various U.K. supplier Web sites. In absolute terms, the annual price premiums to buy 4,000 $\mathrm{kWh}$ vary from $0 \mathrm{GBP}$ for RSPB Energy and npower juice to $26 \mathrm{GBP}$ for unit[e].

${ }^{111}$ EST receives funding from the Department of the Environment, Food and Rural Affairs (DEFRA) and the Scottish Executive as well as from the Department of Trade and Industry (DTI) and the Department for Transport, Local Government and the Regions (DTLR).

${ }^{112}$ For more information, see http://www.est.org.uk/est/est.html?est-future-energy.html
} 


\section{Policies Affecting the Green Power Market}

The United Kingdom has a variety of policies in place to support renewables. In April 2001, the federal government instituted the Climate Change Levy, a tax on electricity and gas purchases by commercial and industrial customers. Green electricity purchases are exempt from the tax. ${ }^{113}$ And although the magnitude of the incentive is significant, the impact of the Climate Change Levy exemption has been diminished by the fact that many industry associations have already entered into voluntary agreements to reduce $\mathrm{CO}_{2}$ and have negotiated tax reductions of up to $80 \%$.

In April 2002, a renewable purchase obligation took effect, requiring electricity retailers to purchase an increasing percentage of their electricity from renewable sources, reaching $10 \%$ by 2010 . Under the policy, companies have to generate their own renewable electricity, buy it from independent producers, or pay a penalty of 4.68 eurocents $/ \mathrm{kWh}$ ( $\sim$ U.S. $4.2 \notin / \mathrm{kWh})$. A green certificate trading system has been developed to implement the policy. ${ }^{114}$

\section{Outlook}

Today, competition in the U.K. retail electricity market is largely price-driven and green electricity has played a minor role. To some extent, the lackluster performance of the green power market can be attributed to a lack of aggressive marketing by the utilities and marketers. There is also some research that suggests that residential customers in the United Kingdom are less willing to pay a premium for green power than customers in other European countries. ${ }^{115}$ However, the recent launch of Npower's "juice" product might indicate a more positive trend in the market. Npower differs from previous residential green power marketers in the United Kingdom in that it has set aggressive targets regarding customer uptake and new capacity, its product carries no price premium, and it is intensely marketing the product in cooperation with the environmental group, Greenpeace. New green power marketers without utility backing are likely to continue finding the retail market challenging and may be more successful among commercial customers who can benefit from Climate Change Levy exemptions. The new renewables obligation creates additional uncertainty in the U.K. green power market because of its potential impact on the consumer demand.

\footnotetext{
${ }^{113}$ For example, EMI Music Company buys green electricity from Ecotricity and saves about 100,000 € p.a. in taxes compared to buying conventional power (Ashley 2001).

${ }^{114} \mathrm{http}: / / w w w . g r e e n p r i c e s . n l / u k / n e w s i t e m . a s p ? n i d=203$, August 28, 2001.

${ }_{115}$ Datamonitor (2000), Wüstenhagen (2000).
} 


\section{Other Countries}

\section{Austria}

The Austrian electricity market has been fully open to competition since October 2001 . Switching activity has been relatively low, with only $0.6 \%$ of residential customers and $6 \%$ of businesses changing suppliers. ${ }^{116}$ Austrian power generation is dominated by hydro $(72 \%)$, with the rest supplied primarily from fossil fuels. The country's dominant generating company, Verbund, has been active branding its existing hydro and selling it to wholesalers and retailers in Germany, Italy, and Austria through its subsidiaries Austrian Power Trading (APT) and Austrian Power Vertrieb (APC). The company has been certified by the German TÜV, which does not require additional environmental improvements at affected waterways. Recently, Verbund and German E.On launched the joint venture European Hydropower to combine their hydropower activities. In Austria, Verbund has launched a joint venture with Raiffeisen Ware Austria, a traditional agricultural logistics group, to market " $100 \%$ domestic hydropower," which is from existing plants and priced equivalent to conventional electricity. ${ }^{117}$ In addition, Verbund has teamed with green power marketer Oekostrom AG to offer its customers a mixture of hydro, wind, biomass, and solar energy.

A few new green power marketers have also emerged. Alpen-Adria-Energy AG (AAE) sells electricity from new small hydro, wind, biomass, and solar power plants and currently serves about 600 customers. ${ }^{118}$ Oekostrom AG is selling green power from wind, biomass, and small hydro to residential customers, and also offers a blend of $20 \%$ green power and $80 \%$ existing large hydro to businesses and public agencies, including the Federal Ministry for Agriculture and Environment. ${ }^{119}$ The company serves about 1,500 customers, and their residential product is the only power product that has been certified under the government's Umweltzeichen eco-labelling scheme thus far. ${ }^{120}$

\section{Belgium}

The Belgian electricity market was opened to competition for large and medium-sized industrial customers in 1999 and 2000, in accordance with European Union (EU) regulations. Belgium has the lowest share of renewables among all EU member countries, with only $1.1 \%$ of total generation supplied from renewable sources and half of this from municipal solid-waste incineration. The country's power generation mix is largely dominated by nuclear power (60\%), natural gas (27\%), and coal (13\%). ${ }^{121}$ Renewable energy policy falls under the domain of the three regions: Flanders, Walloon, and Brussels. The Flemish and Walloon Regions are developing green certificate trading

\footnotetext{
${ }^{116}$ Hujber (2002).

${ }^{117}$ For more information, see http://www.raiffeisen-wasserkraft.at/

${ }^{118}$ For more information, see http://www.aae.at/

${ }^{119}$ For more information, see http://www.oekostrom.at

${ }^{120}$ The Umweltzeichen, like Germany's Blue Angel, certifies environmental products in various categories. Green power has been included in July 2001, for the criteria (in German) see http://www.bmu.gv.at/u_kennzeich_auszeich/oe_umweltzeichen/richtlinien/download/uz46.pdf

${ }^{121}$ RECerT (2000) Country Report, Annex 3, Country Review Belgium, April 2000.
} 
markets to facilitate the implementation of a renewable portfolio standard requiring 3\% of electricity to be generated from renewable sources by 2004 and $5 \%$ by 2010 . The Flemish Region has also instituted an incentive for renewables by exempting power generated from renewable sources from grid charges. ${ }^{122}$

Following the Dutch example, the Flemish Region decided to allow residential customers to switch to green electricity suppliers in the first wave of competition. And although residential customers have been allowed to switch to green power marketers since September 2001, no marketers had offered green products as of late 2001. The country's largest utility, Electrabel, has been teaming with hydropower producers in France (Energie du Rhone) and Switzerland/Italy (Alpenergie), but has not yet introduced a hydropower or other green power product in Belgium thus far.

\section{Denmark}

In 1999, Denmark instituted competition for large electricity customers. Starting in 2003, all customers will have the ability to choose their electricity suppliers. The primary electric generating sources are coal (55\%), natural gas (27\%), wind (12\%), and biofuels $(6 \%)$. There are also a small number of hydroelectric plants that generate a negligible amount of electricity. ${ }^{123}$

There has been limited green power marketing activity in Denmark. In 1998, three municipal utilities - Himmerlands Elforsyning, Herning Kommunale Værker, and ARKE -launched green pricing programs. Under their "Green El" programs, all three utilities offered green power at a premium of $0.05 \mathrm{DKK} / \mathrm{kWh}(\sim \mathrm{U} . \mathrm{S} .1 \not / \mathrm{kWh})$. Herning Kommunale Værker was the most successful, achieving a 1.7\% participation rate. The product was a blend of electricity generated from wind, biomass, and waste incineration. About 600 customers (primarily residential) subscribed and collectively purchased about 2.3 million $\mathrm{kWh}$ of green power. All three programs were put on hold in 1999 in anticipation of electricity market restructuring. ${ }^{124}$

Recently, NESA launched a green power product, in cooperation with the Danish Society for the Conservation of Nature. The company is selling a renewable energy product called Naturstrøm, which is a blend of $60-65 \%$ certified hydro, $5-10 \%$ certified wind and biomass, and $30 \%$ system electricity. The company plans to gradually increase the portion of wind in the mix. The product is designed to meet all of a customer's electricity needs and is sold at a price premium of $0.045 \mathrm{DKK} / \mathrm{kWh}(\sim \mathrm{U} . \mathrm{S} .1 \not / \mathrm{kWh})$. The Swedish Bra Miljoval program certifies the electricity. The company has obtained enough supply to serve 40,000 customers, but no data are available regarding consumer response. ${ }^{125}$

Currently, there is considerable uncertainty regarding policy support for renewable energy sources. The government is considering plans to implement a purchase obligation

\footnotetext{
${ }^{122}$ http://www.greenprices.com/be/newsitem.asp?nid=232, September 29, 2001.

${ }^{123}$ Swedish National Energy Administration (2001).

${ }^{124}$ Koefoed (2002).

${ }^{125}$ For more information, see http://www.nesa.dk.
} 
and a green certificate trading system that would replace all other government subsidies for renewable energy sources. A report outlining plans for the certificate trading system was issued in September 2001; however, the plan has met with significant opposition. ${ }^{126}$ The uncertainty surrounding policy direction appears to be stunting growth in the green power market, as marketers wait for these issues to be resolved.

\section{France}

France has just begun to open its electricity market to competition. While the 1996 European Union directive required member states to open $26 \%$ of the market by February 1999, the French government only started implementing competition in February 2000, giving the 1,200 largest industrial customers the opportunity to choose suppliers. ${ }^{127} \mathrm{Few}$ customers have switched suppliers to date. France's fuel mix is dominated by nuclear $(76 \%)$ followed by large hydro $(13 \%)$, and fossil fuels $(11 \%)$. In fact, France is the largest per capita producer of nuclear power. ${ }^{128}$ Electricité de France (EDF), the largest electric utility in the country, exports nuclear power under long-term contracts to Switzerland, Italy, and other neighboring countries.

Recently the government announced its intention to support wind energy, given growing public concern over nuclear power and the government's interest in meeting greenhouse gas emissions reductions set by the Kyoto protocol and EU targets to double the supply of renewable energy sources. The primary form of support for renewables is a new feedin tariff for wind and small hydro of 7.3 eurocents $/ \mathrm{kWh}(\sim$ U.S. $6.6 \notin / \mathrm{kWh})$ for 15 years.

The green power market in France is in its infancy. In early 2001, EDF was preparing a regional pilot program in North Western France (Lille, Dunkirk), where customers would have been able to purchase green power generated from wind and small hydro at a premium. ${ }^{129}$ However, the local green party opposed the program, believing that government support for renewable energy generators would be more appropriate to promote renewables than voluntary payments from electricity consumers. Therefore, eventually the pilot program was canceled.

\section{Ireland}

In February 2000, the Irish government opened the electricity market to competition. Since then, industrial customers ( $>4 \mathrm{GWh}$ /year) have had access to competitive suppliers, and residential customers have been free to choose green electricity

\footnotetext{
${ }^{126}$ Danish Energy Agency (1999, 2001); PricewaterhouseCoopers (1999); http://www.greenprices.com/eu/newsitem.asp?nid=242, September 28, 2001; http://www.windpower.dk/news/, March 11, 2002

${ }^{127}$ Energy Information Administration, Country Analysis Brief: France http://www.eia.doe.gov/emeu/cabs/france.html

${ }^{128}$ RECerT Country Report, Annex 6, Country Review France, April 2000.

129 "EDF prepares selling green energy in France" http://www.greenprices.nl/nl/newsitem.asp?nid=114, February 20, 2001
} 
suppliers. ${ }^{130}$ While the country obtained all of its electricity from hydropower in 1930 , essentially all new resources added since then have been fossil-based. Today, the fuel mix is $94 \%$ fossil fuels (coal, gas, and oil) and $4.5 \%$ hydro, with some wind and biomass (wood, landfill gas, peat). ${ }^{131}$ The country has relatively good wind resources, and the government intends to increase domestic wind energy output to $7 \%$ of electricity generation.

With respect to the green power market, four suppliers have received licenses to supply green electricity-ESB Independent Energy, Eirtricity, ePower, and The Electricity Company (E. Co.). ESB, an incumbent utility, offers a green power product supplied from existing hydro and wind resources, with some new wind. Eirtricity, a joint venture of National Toll Roads and Future Wind Partnership, intends to develop new on- and offshore wind capacity. The company offers wind power at a $10 \%$ discount compared to the standard ESB tariff for small- and medium-sized businesses. Eirtricity reportedly acquired 9,000 customers between February 2000 and August 2001. ${ }^{132}$ ePower focuses on large industrial customers. ${ }^{133}$ The Electricity Company offers wind energy and claims to have 3,000 customers to date. ${ }^{134}$

\section{Italy}

Prior to 1999, Enel was a state-owned utility and the dominant electric utility in Italy, generating more than $70 \%$ of the country's electricity. Recently, however, the Italian electric power industry has been undergoing a major restructuring, including partial privatization of Enel; and unbundling of Enel's generation, transmission, supply and trading units, and its power generation assets. The market is open to competition for industrial customers ( $>20 \mathrm{GWh} /$ year), but no date has been set for residential competition. The fuel mix in Italy is dominated by fossil fuels, primarily oil-fired power stations (44\%), followed by natural gas $(28 \%)$, and coal $(9 \%)$. Large hydro accounts for $13 \%$ of total generation; and other renewables, such as small hydro and geothermal, account for the remaining 5\%. ${ }^{135}$ Enel constructed four nuclear power plants in the $1980 \mathrm{~s}$, but none of them are currently operating as a result of a public referendum in $1987 .{ }^{136}$ To support renewable energy, the government has recently decided to introduce a purchase obligation that requires large producers and importers ( $>100 \mathrm{GWh} /$ year) to buy $2 \%$ of their electricity from renewables. ${ }^{137}$

\footnotetext{
${ }^{130}$ RECerT Country Report, Annex 9, Country Review Ireland, April 2000; Ouillet, L. (2000) "Le marché de l'électricité verte en Irlande."

${ }^{131}$ Eurostat/European Commission, http://europa.eu.int/comm/energy_transport/etif/energy_electricity/generation.html

132 "eirtricity signs $9,000^{\text {th }}$ customer as sales exceed IR£30 million mark," Company Press Release, August 1, 2001, http://www.eirtricity.ie/news-01-08-2001.htm

${ }^{133}$ For more information, see http://www.epower.ie

${ }^{134}$ Ouillet (2000).

${ }^{135}$ RECerT Country Report, Annex 10, Country Review Italy, April 2000.

${ }^{136}$ Energy Information Administration, Country Analysis Brief: Italy http://www.eia.doe.gov/emeu/cabs/italy.html

${ }^{137}$ RECerT Country Report, Annex 10, Country Review Italy, April 2000.
} 
Although there are no green power product offerings on the market yet, there is growing interest in green power in Italy. Enel has formed a subsidiary called Enel GreenPower (formerly ERGA), which is focusing on renewables. In conjunction with the Association of Renewable Energy Generators (APER) and environmental and consumer organizations, Enel GreenPower launched a 100\% green energy label (100\% Energia Verde) in 2001. ${ }^{138}$ The label will be assigned to renewable generators and to consumers who purchase green power for all of their electricity needs.

\section{Norway}

One of the first countries to undergo deregulation, Norway opened its electricity market to competition in 1991. By 1995, all electricity customers were able to switch suppliers without incurring fees. As of 2000, between 200,000 and 250,000 (about 12\% of total) consumers had switched suppliers. ${ }^{139}$ About $99 \%$ of the country's electricity is generated by hydropower facilities. ${ }^{140}$

In Norway, renewable energy technologies are subsidized through tax exemptions. Renewable energy technologies, such as wind, biomass, micro hydro, and tidal systems, are exempt from investment taxes and subject to electricity taxes at half of the normal level. The Norwegian government has set a goal of generating more than $3 \mathrm{TWh} / \mathrm{year}$ of wind power by 2010, but there are currently no penalties for noncompliance. A green certificate trading system is emerging through Nordpool, the Scandinavian power exchange, which has agreed to issue certificates for the Renewable Energy Certificate System (RECS). The program will allow green power producers to buy and sell green certificates in participating European countries. ${ }^{141}$

Only a handful of Norwegian power providers currently offer green power options to customers. For example, Norsk Vind- og Miljøkraft offers wind power in blocks of $3,000 \mathrm{kWh}$ for an annual fee of NOK 180 , or NOK $0.06 / \mathrm{kWh}(\sim$ U.S. $0.7 \notin / \mathrm{kWh})$. The company owns five $750 \mathrm{~kW}$ wind turbines that supply power for the program. According to the company's 2000 semiannual report, customers had purchased about 250 blocks, or about $6 \%$ of the total number available. Another company, a small, independent power producer called Mikrokraft, offers a green power product supplied from micro hydro facilities at a discount of NOK $0.02(\sim$ U.S. $0.2 \varnothing / \mathrm{kWh})$ below standard offer rates. In 2000 , the state-owned power company Statkraft announced plans to market Norwegian hydropower as green electricity throughout Europe at a price premium of about $10 \% .{ }^{142}$ However, no information is available on consumer response to the product. Recently, Statkraft exported about $25 \mathrm{GWh}$ of power from its existing small hydro facilities to the Dutch green certificate market. ${ }^{143}$ There are no green power certification programs in

\footnotetext{
${ }^{138}$ http://www.greenprices.nl/nl/newsitem.asp?nid=180, June 29, 2001; For more information, see http://space.virgilio.it/centopercentoverde@virgilio.it

${ }^{139}$ The European Renewable Electricity Certificate Trading Project (RECerT) (2001).

${ }^{140}$ Swedish National Energy Administration (2001).

141 Nordpool http://www.nordpool.no and the Renewable Energy Certificate System http://www.recs.org, accessed February 2000.

${ }^{142}$ Financial Times (2000c).

${ }^{143}$ http://www.greenprices.com/eu/newsitem.asp?nid=311, March 27, 2002.
} 
Norway, but the Swedish Society for Nature Conservation's Bra Miljöval program certifies at least one Norwegian green power marketer.

Norway's green power market has been slow to develop, perhaps in part, because hydropower provides nearly all of the country's electricity. In addition, misleading claims by an early market entrant led to unfavorable publicity for green power. ${ }^{144}$ In the future, there are likely to be additional opportunities for Norwegian renewable energy generators to trade renewable energy certificates from hydro projects and other renewables internationally.

\footnotetext{
${ }^{144}$ RECerT (2001).
} 


\section{Comparison of Markets: Consumer Response and Issues Affecting Green Power Market Development}

This section discusses factors that affect consumer demand for green power in the countries examined in this report. Table 13 summarizes data on the number of marketers active in the markets considered here as well as overall consumer response in terms of both customers and green energy purchases. It also includes estimates of the new renewable energy capacity installed in each country to meet consumer demand for green power.

\section{Consumer Response}

Globally, market penetration rates for green power are typically about $1 \%$ (see Table 13 ). The most notable exception is in the Netherlands, where about $13 \%$ of households are purchasing green power products. The relative success of the Dutch market can be explained by three factors: 1) a tax exemption for renewables sold as green power, 2) aggressive marketing campaigns by utilities and marketers, and 3) a restructuring policy that granted green power suppliers retail access in advance of full retail competition. Green electricity sales are exempt from the federal ecotax, which is currently set at about 5.5 eurocents $/ \mathrm{kWh}(\sim$ U.S. $5 \not / \mathrm{kWh})$ for small customers. The credit has enabled marketers to reduce premiums for green power, although many still charge a slight premium for their products. The low prices have fueled consumer interest. In addition, just prior to the start of retail competition, Dutch marketers and utilities launched aggressive marketing campaigns, including expensive television advertisements featuring green power, designed to retain customers and increase loyalty in the face of competition. Finally, the marketing focus has been on green power because residential customers gained access to green power providers in July 2001, but they will not have access to conventional power providers until late 2003.

With respect to non-residential purchases of green power, Sweden is the current leader with annual green power sales of more than 9 million MWh. The success of this market has been driven by the availability of large quantities of existing hydropower that can be sold at relatively low cost. The hydro has been repackaged for business customers and sold as a separate, environmentally preferred product - in many cases, at the same cost as generic power. To date, there has been minimal environmental improvement realized from these sales because the supply is primarily from existing projects. However, some certified products have required that the hydropower plant owners invest in environmental improvements to minimize the impact of dams on wildlife and habitats.

\section{Product Design and Renewable Content}

Most green power offerings have been designed to meet all or a portion of a consumer's energy needs; these are often called "energy-based" products. The other dominant design is referred to as a "contribution" program, through which customers can make donations to a fund that supports the development of new renewable resources. Contribution 
programs are less common, but have been offered in countries such as the United Kingdom and Japan and, to a limited extent, Australia.

Generally, green power marketers have offered a range of products to appeal to customers with varying price sensitivities and resource preferences. The majority of products consist of a blend of renewable resources, such as biomass, hydro, wind, and solar, offered at moderate to low price premiums. In Europe, the inclusion of large hydro

Table 13: Comparison of Consumer Response to Green Power

\begin{tabular}{|c|c|c|c|c|c|c|}
\hline & $\begin{array}{c}\text { Marketers/ } \\
\text { Utilities } \\
\text { (approx \#) }\end{array}$ & $\begin{array}{c}\text { Estimated } \\
\text { Green } \\
\text { Power } \\
\text { Customers } \\
\text { (approx \#) }\end{array}$ & $\begin{array}{c}\text { \% of } \\
\text { Residential } \\
\text { Customers }\end{array}$ & $\begin{array}{c}\text { Estimated } \\
\text { Green } \\
\text { Electricity } \\
\text { Sales } \\
\text { (million } \\
\text { kWh/year) }\end{array}$ & $\begin{array}{l}\% \text { of Total } \\
\text { Electricity } \\
\text { Sales }\end{array}$ & $\begin{array}{c}\text { Estimate of } \\
\text { New } \\
\text { Renewable } \\
\text { Capacity } \\
\text { Developed }\end{array}$ \\
\hline \multicolumn{7}{|l|}{ N. America } \\
\hline Canada & $<10$ & 6,500 & $0.5 \%^{2}$ & $>150$ & $0.03 \%$ & $>70 \mathrm{MW}$ \\
\hline U.S. & $>100$ & $375,000^{3}$ & $1 \%{ }^{4}$ & 2,000 & $0.1 \%$ & $650 \mathrm{MW}$ \\
\hline \multicolumn{7}{|l|}{ Europe } \\
\hline Finland & $>30$ & 8,000 & $0.4 \%$ & 156 & $0.2 \%$ & $\mathrm{~N} / \mathrm{a}$ \\
\hline Germany & $>100$ & 325,000 & $1 \%$ & 900 & $0.2 \%$ & $10 \mathrm{MW}$ \\
\hline Ireland & $<10$ & 12,000 & $1 \%$ & $\mathrm{~N} / \mathrm{a}$ & $\mathrm{N} / \mathrm{a}$ & $\mathrm{N} / \mathrm{a}$ \\
\hline Netherlands & $>15$ & 775,000 & $13 \%$ & 2,500 & $3 \%$ & $\mathrm{~N} / \mathrm{a}$ \\
\hline Sweden & $>50$ & $\mathrm{~N} / \mathrm{a}$ & $\mathrm{N} / \mathrm{a}$ & 9,000 & $6 \%$ & $\mathrm{~N} / \mathrm{a}$ \\
\hline Switzerland & $>100$ & 46,000 & $2 \%$ & $150^{5}$ & $0.3 \%$ & $10 \mathrm{MW}^{6}$ \\
\hline U.K. & $>10$ & 45,000 & $0.2 \%$ & $150^{5}$ & $0.04 \%$ & $\mathrm{~N} / \mathrm{a}$ \\
\hline \multicolumn{7}{|l|}{ Other } \\
\hline Australia & $>15$ & 68,000 & $1 \%$ & 460 & $0.3 \%$ & $200 \mathrm{MW}^{7}$ \\
\hline Japan & $>10$ & 38,000 & $0.1 \%$ & 25 & $0.003 \%$ & $12 \mathrm{MW}$ \\
\hline TOTAL & $>450$ & $\sim 1,700,000$ & -- & $\sim 18,000$ & -- & $>950 \mathrm{MW}$ \\
\hline \multicolumn{7}{|c|}{$\begin{array}{l}{ }^{1} \text { Customer estimates are based on supplier claims and information provided by certification programs. } \\
{ }^{2} \text { Not all customers in Canada have access to green power options. The fraction is about } 0.5 \% \text { of } \\
\text { residential customers in Alberta. Marketers in other regions only recently launched programs. } \\
{ }^{3} \text { In addition, marketers supply an estimated } 450,000 \text { customers with "clean" electricity products in } \\
\text { which a small portion of the electricity is generated from renewables (e.g., } 1-2 \%) \text {. } \\
{ }^{4} \text { Percentage based on the number of customers that have the option to switch to a green electricity } \\
\text { supplier or purchase green electricity from the local utility. } \\
{ }^{5} \text { Includes only solar, wind and biomass. } \\
{ }^{6} \text { Capacity installed to serve residential customers only. } \\
{ }^{7} \text { Another } 400 \mathrm{MW} \text { of capacity is planned for } 2002 \text {. }\end{array}$} \\
\hline
\end{tabular}

has been common, whereas, use of hydro has been limited to small or low-impact projects in other areas. Generally, products heavily dependent on existing, large hydro resources have been sold at the same cost as system power or at very modest premiums, with the revenues typically used to fund mitigation efforts and environmental improvements at affected waterways. In Germany, a number of marketers have offered products that blend power from renewable sources and cogeneration at moderate price premiums. In the Netherlands, municipal solid waste has been included in green power products, although it has generally been excluded elsewhere. At the higher end of the price spectrum, utilities and marketers have offered products featuring, most commonly, new wind or sometimes solar. 
Given that many products have initially been supplied with power from existing renewable electric projects, green power markets on the whole have so far had only a slight impact on the development of new renewable resources. However, new capacity additions to serve green power customers are growing, particularly in areas such as Australia, where certification programs require a significant fraction of the power content to be supplied from new resources. Further, growth is likely in many markets that are still young and where green power demand has not yet spurred new capacity development. For example, in the Netherlands, green power sales now exceed domestic supplies. This strong demand is likely to drive the development of new resources, either in the Netherlands or in surrounding areas, in the near future. In areas with large amounts of power available from existing renewable electric projects, the challenge may be for certification groups and consumers to encourage marketers to include more new renewables in their products.

\section{Pricing}

Most green power products have been offered at modest price premiums on the order of U.S. $0.5 \phi / \mathrm{kWh}$ to $1.5 \phi / \mathrm{kWh}$. In some cases, green power has been offered at prices below standard electricity service, such as in Germany, Finland, and the Netherlands. On the other hand, a number of products, typically those that have featured new wind or solar resources, have been offered at relatively high price premiums in the range of U.S. $2 \phi / \mathrm{kWh}$ to $6 \phi / \mathrm{kWh}$ or more. These higher-priced products have typically been targeted at the most environmentally concerned consumers interested in purchasing products that yield the greatest environmental benefits.

Overall, markets offer conflicting evidence as to whether price significantly influences demand. In the Netherlands, where price premiums have been very low, consumer demand has been so strong that it has exceeded available domestic renewable energy supplies. Similarly, in Germany, the majority of the roughly 325,000 customers are purchasing green power at no premium or at a slight discount to standard utility rates. And, in Sweden, green power represents about $6 \%$ of all electricity sales - and much of this demand is from commercial and industrial customers who are purchasing products supplied from existing hydro projects with very low or perhaps no premiums.

On the other hand, the Finnish market offers some evidence to suggest that price is not the only factor affecting purchase decisions. A number of green power products in Finland have been offered at prices below the cost of conventional power, yet consumer response has been fairly modest, with less than $1 \%$ of customers selecting green power. According to one study of the Finnish market, the modest demand can be explained by factors such as inadequate marketing and a lack of consumer awareness of the current fuel mix, cleaner power options, and the price of those options. Also, a comparison of the Dutch and U.K. experience shows that similar levels of price premiums can result in completely different response rates, depending on how actively and skillfully marketers promote their products. Finally, Switzerland and the United Kingdom have similar 
numbers of green power customers, even though price premiums for the popular solar power products in Switzerland have been significantly higher.

\section{Market Structure}

Green power marketing has been concentrated in areas where retail competition has been established or where it is being phased-in. Japan and Switzerland are the notable exceptions in that no firm plans are in place to restructure the electricity market. In Switzerland, however, the issue is receiving considerable attention-and restructuring could begin as early as this year, if the public approves draft legislation. Prior to the onset of retail competition, utilities in many countries, including the United Kingdom, Switzerland, Japan, Germany, and the Netherlands, have offered green power options to their captive customers. Generally, they have done so to encourage customer loyalty when competition ensues and to gain experience with marketing differentiated products and renewables.

Typically, the start of competition in the residential sector has sparked an increase in green power marketing. For example, until recently green power marketing activity in Canada has been centered in Alberta, the first retail market to open to competition. Recently, several companies have begun positioning themselves to offer green power products in Ontario, where residential customers will be able to choose alternative suppliers shortly. The Dutch market also experienced a flurry of activity prior to July 2001, when residential customers gained access to green power suppliers. In fact, the priority given to green consumers in the Netherlands has been a critical factor driving the success of the market. This does not appear to be the only ingredient to creating a successful market, however, because Ireland and Belgium both have similar policies in place, but their green power markets are developing more slowly than the Dutch market.

Although the prospect of a competitive market appears essential for spurring green power marketing, evidence from markets to date suggests that customers are not necessarily interested in switching suppliers to purchase green power. Of the 775,000 green power customers in the Netherlands, only about 50,000 have switched suppliers. Similarly, in Finland, only about one-third of the green customers have switched suppliers. And, in Germany, one default supplier alone serves nearly half of the country's 325,000 green power customers. This lack of switching may be explained in part by the fact that many markets have not been open to competition for very long, and customers simply have not had time to research options and become comfortable with switching. Switching presents a hurdle for risk-averse customers or for those lacking knowledge about their options and about competition in the electric industry in general. Further, competitive activity in general depends on a clear regulatory framework, particularly non-discriminatory grid access. The lack of such regulation helps explain the low switching rates in Germany, whereas in the United Kingdom and Norway switching rates are much higher due to market rules that are amenable to competition. Over time, switching is likely to increase as markets mature, mirroring the experience in other previously regulated markets, such as telecommunications. 


\section{Certification/Labeling Programs}

In most countries, certification or labeling programs have emerged to provide consumers with confidence that their green power purchases are 1) from environmentally preferred sources and 2) supplied in the appropriate quantity. These programs have proven to be important for shaping the renewable energy content of green power products and verifying purchases. In most markets, certification programs set standards for the renewable energy content of green products and a significant number of suppliers have sought certification. Perhaps the most striking example of the influence of certification on product content is in Australia, where suppliers are required to obtain $80 \%$ of their green power from new renewable sources in order to be certified. Thus far, suppliers have been successful in meeting the new renewables standard. Verification has also been an important function of some certification programs, although green certificate trading systems may assume some role in the future.

The nature of certifying organizations varies from country to country. Programs have been founded by government agencies, environmental organizations, and organizations with experience certifying other products. The government has played a key role in establishing certification programs in the United Kingdom, Canada, and Australia, whereas in Switzerland, Sweden, Germany, and Finland, non-governmental organizations are emerging as the dominant certifiers. Interestingly, the Netherlands, which has the most green power customers, has no widely established labeling program in place. Instead, it has a certificate trading system, which aids in product verification. One benefit to government involvement is that a single label and a single certification standard exist in the market. When competing labels emerge, it is more challenging to garner consumer recognition and awareness of the labels. However, competition among labels may reflect an early stage of market development where no consensus about environmental standards has been reached yet. A disadvantage of government-driven labels is that they tend to require more time to address issues and emerging markets.

\section{Impact of Renewable Energy Policies on the Green Power Market}

Renewable energy policies directly and indirectly impact the market for green power. Below, we explore the impact of taxes and subsidies, purchase obligations (or renewable portfolio standards), feed-in tariffs, and green certificate trading programs, which are the policies that we found have the most direct impact on consumer demand for green power.

Tax Exemptions/Subsidies - Tax exemptions for green power purchases have lowered the costs of green power products, in some cases, to levels below standard rates. Marketers also typically benefit from increased profit margins, which enable them to enter competitive markets and perhaps undertake more aggressive marketing campaigns. As discussed previously, the REB tax exemption in the Netherlands has successfully stimulated demand for green power. The policy, which exempts small electricity consumers from paying the ecotax on green power purchases, has fueled aggressive green power marketing campaigns by utilities and competitive marketers. Consumer response 
has been so favorable that demand has exceeded the country's supply of renewables, causing marketers to look outside of the country for supplies.

In contrast to the Dutch experience, tax policies in the United Kingdom and Norway have had more modest effects on the market. In Norway, renewable energy sources are exempt from investment taxes and subject to only half of the standard electricity sales tax. The incentives have done little, however, to stimulate the market, with only a few suppliers offering products in the marketplace. In the United Kingdom, commercial and industrial customers must pay a Climate Change Levy on electricity and gas purchases, unless they purchase green power. The incentive has been largely ineffective to date, primarily because many industries have negotiated levy reductions with the government for undertaking voluntary $\mathrm{CO}_{2}$ reduction measures, leaving the green power tax exemption largely inconsequential.

Purchase Obligations - A number of countries have instituted purchase obligations requiring retail suppliers to include some amount of renewables in their resource portfolios. To date, Australia, Belgium, Denmark, Italy, Sweden, and the United Kingdom have adopted or plan to implement such policies. Purchase obligations may impact consumer demand for green power. One theory is that customers might not be interested in paying a premium for green power if a portion of their power is already supplied from renewables. However, it is too early to determine the impact because most policies have only recently been adopted and some have yet to take effect. Australia's purchase obligation took effect in 2001, and the impact appears to be negligible so fargreen power sales increased by about $50 \%$ as of the first half of $2001{ }^{145}$ Uncertainty surrounding the policy in Denmark has largely stifled the development of the country's green power market. Overall, it is perhaps too early to tell what impact purchase obligations will have on consumer demand for green power, but it is clear that policy uncertainty can have a detrimental affect on market development.

Feed-in Tariffs for Renewables - Germany and Spain, and more recently France, have emphasized direct support of renewable energy generation rather than providing incentives on the retail side of the market. For example, renewable generators in Germany receive guaranteed minimum fixed-price payments for each $\mathrm{kWh}$ that they supply to the grid. These payments are then evenly shared among all electricity consumers. In 2000, the German government significantly increased the feed-in tariffs, particularly for PV, which now receives about 48 eurocents $/ \mathrm{kWh}(\sim \mathrm{U} . \mathrm{S} .43 \notin / \mathrm{kWh})$, while wind generators get about 9 eurocents $/ \mathrm{kWh}(\sim \mathrm{U} . \mathrm{S} .8 \notin / \mathrm{kWh})$. This has given a boost to renewable generation capacity, but the impact on the retail green power market is unclear. As with purchase obligations, customers may not be interested in purchasing green power if they think that renewables are already supported nationally. From the marketer's point of view, it becomes difficult to argue why someone should pay a premium if the supply comes from generators that have already received support from the feed-in tariff. While it is difficult to state with certainty the real impact on demand, it appears that the German feed-in policy has made it more difficult for green power marketers to build a case for their products.

${ }^{145}$ Cribb and Saltman (2002). 
Green Certificate Trading Programs-A number of countries have developed or are developing green certificate trading programs, typically to implement a renewable purchase obligation. Australia and the Netherlands have systems in place, and Denmark, Norway, Sweden, and the United Kingdom plan to develop systems. There is also a European-wide renewable energy certificate system (RECS) that hopes to integrate the individual systems so that transboundary trading will be possible. While there has been little international trade in green power so far, the creation of coordinated trading systems has the potential to facilitate increased cross-border trading. As with purchase obligations, it is too soon to determine the impact that these programs will have on the green power market. Clearly, trading systems have the potential to make it easier for marketers to obtain renewable energy supplies. Green certificates also provide a formal mechanism for tracking renewable energy purchases and verifying product content, which can give consumers confidence in the source of their electricity and enable certification groups to more easily verify energy sources. Trading systems may also result in more fluid markets and facilitate international trading, which could increase access to and perhaps lower the costs of renewable energy supplies.

\section{Summary}

In summary, we find that market penetration rates beyond $10 \%$ are achievable if market conditions are favorable to green power. Most markets, however, have experienced penetration rates of about $1 \%$ or less, similar to the United States. In general, green power markets are young and, as is the case with most new markets, require time to develop. Based on our review, the following factors can aid in fostering the development of green power markets: aggressive and cooperative marketing efforts by utilities and competitive providers, incentives and other policies that reduce the cost of renewable energy, restructuring rules that give priority to green power customers, market rules that enable competition to ensue, certification standards that encourage new renewables development, government purchases that stimulate demand, and consumer education that addresses the availability and benefits of green power options. 


\section{Bibliography}

Ashley, J. (2001). "Demand From Corporate Customers: A Market Opportunity for Suppliers of Green Power." Wüstenhagen, R.; Giger, N. (eds.). First European

Conference on Green Power Marketing, proceedings. St. Moritz, June 29-30, 2001.

Bratrich, C.; and Truffer, B. (2001). “Ökostrom-Zertifizierung für Wasserkraftanlagen, Ökostrom-Publikationen,” Band 6, EAWAG, Kastanienbaum.

Brusa, A. (2000). "RECerT Country Report," Annex 10, Country Review Italy. April 2000.

Canadian Wind Energy Association (Canwea) (1999). Low Impact Renewable Energy: Options for a Clean Environment and a Healthy Economy. Calgary, Alberta. http://www.canwea.ca/documentsen.htm1999.

Coleman, S. (2001). "Wadden Sea Project Under Fire.” Het Financieele Dagblad (English), October 3, 2001.

Cribb, P. and N. Saltman (2002). Personal communication. Sustainable Energy Development Authority, New South Wales, Australia. January 13.

Cribb, P. (2002). Personal communication. Sustainable Energy Development Authority, New South Wales, Australia. April 12.

Datamonitor (2000). The Datamonitor Green Energy Survey, executive summary. London.

Danish Energy Agency (1999). Report on the Danish Green Certificate Market.Copenhagen, Denmark. December 1999.

Danish Energy Agency (2001). "The Green Certificate Market in Denmark: Status of Implementation." Copenhagen, Denmark. http://www.ens.dk/uk/publica.htm\#Green\%20Market. September 2001.

ECN (2000). Energy Market Trends in The Netherlands 2000.

Dogterom, Jon (2002). Personal communication. Pembina Institute, Vancouver, Canada. April 26, 2002.

Ecofys (2001). "Electricity from Renewable Energy Sources in the Netherlands: Current Status and Prospects," proprietary report. Utrecht. October 2001.

Econcept/EAWAG (2001). Kennzeichnung von Elektrizität, Mögliches Vorgehen gemäss Art. 12 EMG, Report on behalf of the Federal Energy Agency (BFE), Berne January 2001. http://www.econcept.ch/pdf/422_sb.pdf 
Energy Information Administration (EIA) (2001a). "Country Analysis Brief: Australia." U.S. Department of Energy. Washington, D.C.

http://www.eia.doe.gov/emeu/cabs/australi.html. June 2001.

EIA (2001b). “Country Analysis Brief: Japan”. U.S. Department of Energy. Washington, D.C.

http://environment.about.com/gi/dynamic/offsite.htm?site=http $\% 3 \mathrm{~A} \% 2 \mathrm{~F} \% 2 \mathrm{Fwww}$.eia.do e.gov\%2Femeu\%2Fcabs\%2Fjapan.html. April 2001.

EnergyInfo Source, Inc. (2000). "Japanese Power Firms to Create Green Electricity Program.” Green Power Report. June 26, 2000.

Enmax (2000). "ENMAX Hybrid Electric Car Spreads News About Green Power.” News release. June 16, 2000.

Environmental Resources Management (ERM) (2001). National Green Power Annual Audit (Compliance Audit). Prepared for Sustainable Energy Development Authority (SEDA). February 2001.

Epcor (2000). "EPCOR Invests in Power of the Wind.” News release. September 13, 2000.

Epcor (2001). “Capital City Savings Signs Up as EPCOR's First Commercial Green Power Customer." News release. June 11, 2001.

European Renewable Electricity Certificate Trading Project (RECerT) (2001). Country Report. Annex 13. http://recert.energyprojects.net/GetDoc.asp?documentID=36. June 2001.

Europower (2001). "Number of Swedish Power Companies Drastically Reduced." www.europower.com. November 1, 2001.

Financial Times (2000a). "Demand for Green Electricity Remains Strong." Renewable Energy Report, 22 (December): 14, 2000.

Financial Times (2000b). "Green Certificate Trading Planned for 2003." Renewable Energy Report, 17 (July): 9, 2000.

Financial Times (2000c). "Statkraft to Market Green Power." Renewable Energy Report, 12 (February): 10, 2000.

Financial Times (2001a). "Green Sales Rise Sharply.” Renewable Energy Report, 29 (July): 20, 2001. 
Financial Times (2001b). "TenneT Issues Dutch Tradable Green Certificate." Renewable Energy Report, 30 August 2001, p. 17.

Financial Times (2001c). “Green Market Expands.” Renewable Energy Report, 32 October 2001, p. 15.

Financial Times (2002). "Canadian Federal Budget Supports Wind" Renewable Energy Report, 35 January 10, 2002, p. 3.

Finnish Association for Nature Conservation (1999). Ecolabelling of Energy - Criteria 2000. Helsinki, Finland. http://www.sll.fi/energia/ecolabelling.html. December 1999.

Finnish Energy Industries Federation (2001). "Electricity Year 2000.” Helsinki, Finland. http://lehdisto.energia.fi/finergy/Press\%20Release/\%23380270. January 1, 2001.

Finnish Energy Market Authority (2001). Annual Report 2000. Ministry of Trade and Industry. Helsinki, Finland. http://www.energiamarkkinavirasto.fi/eng/index.html

Fry, R. (2001). "Swedish companies forced to sell green electricity, prices may rise." EuroPower.com. http://www.europower.com/site/ep article.php3? artid=660, October 5, 2001.

Future Wind Holdings Ltd. (2000). "RECerT Country Report," Annex 9, Country Review Ireland. April 2000.

Greenprices.com (2001). Greenprices.com Web site. http://www.greenprices.com/se. Utrecht, the Netherlands. Accessed October 29, 2001.

Haas, R. et al. (2001). Review Report on Promotion Strategies for Electricity from Renewable Energy Sources in EU Countries. Vienna. June 2001.

Hall, Allen. "Green energy plan may generate German windfall." The Evening Standard (London). June 22, 2001. p. 40.

Heijnes, Heddeke. (2002). Greenprices.com. Personal communication. Utrecht, The Netherlands, April 25, 2002.

Holt, E. (2001). "European Green Power Marketing Conference: Same Issues, Different Responses." EPRI Newsflash Electric Power Research Institute. Palo Alto, California. July 16, 2001.

Hopkins, Caroline. (2001). Swedish Society for Nature Conservation, Stockholm, Sweden. Personal communication. November 7, 2001.

Howland, Theresa. (2002). Personal communication. Enmax Energy Corporation, Calgary, Canada. April 10, 2002. 
Hujber, A. (2002). Electricity Market Liberalisation - The Austrian Experience, presentation at the Global Expertise '02 Electricity Marketing Conference, VaasaEMG, University of Vaasa, February 6-7, 2002.

Japan Natural Energy Company (2001). "First Contract under Green Power Certification System.” News release. http://www.natural-e.co.jp/press1-e.html. April 5, 2001.

Japan Natural Energy Company (2000) “Japan Natural Energy Company Limited Established." News release. http://www.tepco.co.jp/corp-com/press/2000101201-e.html. April 5, 2001.

Kaberger, Tomas. (2002). Ecotraffic Energy Research, Development, Demonstration \& Deployment, Göteborg, Sweden. Personal communication. April 16, 2002.

Koefoed, Anne Louise. (2002). Norwegian School of Management, Sandvika, Norway. Personal communication. April 23, 2002.

Lovell, H. (1998). "Green Electricity in the U.K.: A Significant New Product for the Renewable Energy Industry?” thesis. Oxford University (supervisor: Dr Brenda Boardman). Oxford. September 1998.

National Electricity Market Management Company (NEMMCO) (2001). “An Introduction to Australia's National Electricity Market: A Summary of the State of RE Power Generation in Australia." http://www.nemmco.com.au/publications/whitebook/introbook.htm. May 15, 2001.

Natural Resources Canada (2000). "Federal Purchases of Electricity from Emerging Renewable Sources Under Action Plan 2000," No. 7. November 27, 2000.

Natural Resources Canada (1999). “Canada's Emissions Outlook: An Update.” Analysis and Modelling Group, National Climate Change Process. http://nrcan.gc.ca/es/ceo/update.htm. December 1999.

Office of the Renewable Energy Regulator (2001). "Overview of the Mandatory Renewable Energy Target." http://www.orer.gov.au/overview.htm (accessed November 30, 2001).

OFGEM (2001): Guidelines on Green Supply Offerings, Consultation Document, December 2001, http://www.ofgem.gov.uk/docs2001/81_green.pdf Ouillet, L. (2000). "Le marché de l'électricité verte en Irlande.” Ecofys. Utrecht. Palmers, G. (2000). "RECerT Country Report," Annex 3, Country Review Belgium. April 2000.

Ohbayashi, Mika (2001). Personal communication, Institute for Sustainable Energy Policies, Tokyo, Japan, December 21, 2001. 
Pape, A.; Hornung, R.; and Cowan, J. (1999). "Lost Opportunities: Canada and Renewable Energy, A Cross-Country Comparison of Government Support for Renewable Energy." Pembina Institute. Ottawa, Ontario. September 1999.

Pape, Andrew. (2001). Personal communication. Pembina Institute, Vancouver. October $10,2001$.

Persson, N. (2001). EuroPower.com

http://www.europower.com/site/ep_article.php3?artid=778. November 1, 2001.

PricewaterhouseCoopers (1999). "Organization of RE Market and Trading of Green Certificates.” Hellerup, Denmark. October 1999.

Raynolds, M.; and Pape, A. (2000). The Pembina Institute Green Power Guidelines for Canada. Pembina Institute. Drayton Valley, Alberta. July 2000.

Sustainable Energy Development Authority (SEDA) (2000a). National Green Power Accreditation Program Quarterly Status Report. June 2000.

SEDA (2000b). "Success of National Green Power: Facts And Growth Trends 3 Years On.” http://www.greenpower.com.au/download.shtml. October 2000.

SEDA (2001a). "The Green Power Accreditation Program 2000-01: The Unaudited Results." http://www.greenpower.com.au/download.shtml. 2001.

SEDA (2001b). National Green Power Accreditation Program Quarterly Status Report. June 2001.

SEDA (2001c). National Green Power Accreditation Program: Accreditation Document, Version 2. New South Wales. http://www.greenpower.com.au/download.shtml.

November 2001.

Swedish National Energy Administration (2001). Electricity Market 2001. Department of Energy Policy Analysis. Eskilstuna, Sweden.

http://www.stem.se/web/biblshop eng.nsf/FilAtkomst/ELMARK01eng1 14MBl.pdf/\$FI LE/ELMARK01eng1_14MBl.pdf?OpenElement. August 2001.

Swedish Society for Nature Conservation (2001a). New Criteria for Good Environmental Choice Labeled Electricity. Goteborg, Sweden.

http://www.snf.se/bmv/english/index.htm. July 12, 2001.

Swedish Society for Nature Conservation (2001b). Bra Miljöval Certification Program. Goteborg, Sweden. http://www.snf.se/bmv/english/index.htm. Accessed November 2001. 
Swezey, B. and L. Bird (2000). Green Power Marketing in the United States: A Status Report, NREL/TP-620-28738. Golden: CO: National Renewable Energy Laboratory, August 2000.

Swezey, B. and L. Bird (2001). Utility Green Pricing Programs: What Defines Success? NREL/TP-620-29831 Golden: CO: National Renewable Energy Laboratory, August 2001

Tepponen, Sirkka. (2002). Personal communication. Finnish Association for Nature Conservation, Helsinki, Finland, April 24, 2002.

Tokyo Electric Power Company (2000). "Establishment of Green Power Fund." News release. http://www.tepco.co.jp/corp-com/press/2000092701-e.html. September 27, 2000.

Traube, K.; Schulz, W. (2000). Ökologische und ökonomische Wirkung eines mittelfristigen Ausbaus der Kraft-Wärme-Kopplung zur Nah-/Fernwärmeversorgung in Deutschland. Oberursel, June 2000. http://www.vku.de/download/traube.exe, pp. 6 and 16.

Truffer, B.; Markard, J.; and Wüstenhagen, R. (2001). "Eco-labeling of Electricity Strategies and Tradeoffs in the Definition of Environmental Standards." Energy Policy 29 (2001). pp. 885-897.

University of Vaasa, Department of Marketing (2001). Green Electricity in Finland. Vaasa, Finland. http://www.vaasaemg.com/index pricewatchE.html. May 2001.

Van Vliet, B.; Wüstenhagen, R.; and Chappells, H. (2000). "New Provider-Consumer Relations in Electricity Provision. Green Electricity Schemes in the U.K., the Netherlands, Switzerland and Germany." Paper presented at the Business Strategy \& the Environment Conference, Leeds. September 18-19, 2000.

Wiser, R., M. Bolinger, E. Holt, and B. Swezey (2001). Forecasting the Growth of Green Power Markets in the United States, NREL/TP-620-30101, Golden: CO: National Renewable Energy Laboratory, October 2001.

Wüstenhagen, R. (1998). "Green Electricity in Switzerland. A Mere Eco-Niche or the first Step Towards a Sustainable Energy Market at Large?" in Conference Proceedings International Association for Energy Economics (eds.): Energy Markets: What's New? Berlin, pp. 143-151.

Wüstenhagen, R. (2000). "Ökostrom - von der Nische zum Massenmarkt (Green Power Marketing - from Niche to Mass Markets)," vdf Hochschulverlag, Zurich.

ZEW (2000). "RECerT Country Report," Annex 6, Country Review France. April 2000.

Wüstenhagen, R., J. Markard, and B. Truffer (2002). Diffusion of Green Power Products in Switzerland, forthcoming in Energy Policy. 


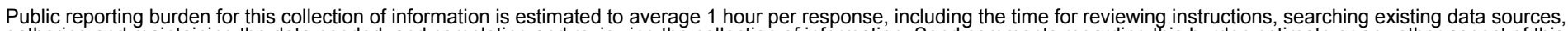

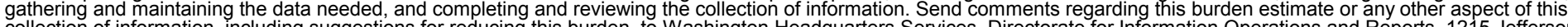
Davis Highway, Suite 1204, Arlington, VA 22202-4302, and to the Office of Management and Budget, Paperwork Reduction Project (0704-0188), Washington, DC 20503.
1. AGENCY USE ONLY (Leave blank)
2. REPORT DATE
April 2002
3. REPORT TYPE AND DATES COVERED
Technical Report - Analysis

\section{TITLE AND SUBTITLE Green Power Marketing Abroad: Recent Experience and Trends}

5. FUNDING NUMBERS

6. $\operatorname{AUTHOR}(\mathrm{S})$

Lori Bird, Rolf Wüstenhagen, and Jørn Aabakken

TA: AS72-1006

7. PERFORMING ORGANIZATION NAME(S) AND ADDRESS(ES) National Renewable Energy Laboratory

1617 Cole Blvd.

Golden, CO 80401-3393

9. SPONSORING/MONITORING AGENCY NAME(S) AND ADDRESS(ES)

National Renewable Energy Laboratory

1617 Cole Blvd.

Golden, CO 80401-3393
8. PERFORMING ORGANIZATION REPORT NUMBER

\section{SUPPLEMENTARY NOTES}

NREL Technical Monitor:

12a. DISTRIBUTION/AVAILABILITY STATEMENT

National Technical Information Service

U.S. Department of Commerce

5285 Port Royal Road

Springfield, VA 22161

13. ABSTRACT (Maximum 200 words)

Green power marketing--the act of differentially selling electricity generated wholly or in part from renewable sources--has emerged in more than a dozen countries around the world. This report reviews green power marketing activity abroad to gain additional perspective on consumer demand and to discern key factors or policies that affect the development of green power markets. The objective is to draw lessons from experience in other countries that could be applicable to the U.S. market.

14. SUBJECT TERMS

green power marketing; green electricity; green energy; utility green pricing; customer choice; retail competition; international renewable energy policy; product certification; accreditation; renewable energy certificate trading; Australia; Canada; Finland; Germany; Japan; The Netherlands; Sweden; Switzerland; United Kingdom.

\begin{tabular}{l|l|l} 
17. SECURITY CLASSIFICATION & $\begin{array}{l}\text { 18. SECURITY CLASSIFICATION } \\
\text { OF REPORT } \\
\begin{array}{l}\text { OF THIS PAGE } \\
\text { Unclassified }\end{array}\end{array}$ & $\begin{array}{l}\text { 19. SECURITY CLASSIFICATION } \\
\text { OF ABSTRACT } \\
\text { Unclassified }\end{array}$
\end{tabular}

NSN 7540-01-280-5500
15. NUMBER OF PAGES

16. PRICE CODE

20. LIMITATION OF ABSTRACT

UL
10. SPONSORING/MONITORING AGENCY REPORT NUMBER

NREL/TP-620-32155 